\title{
Multifunctional Polymeric Nanoplatforms for Brain Diseases Diagnosis, Therapy and Theranostics
}

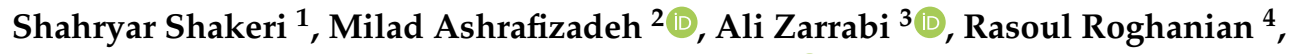 \\ Elham Ghasemipour Afshar ${ }^{5}$, Abbas Pardakhty ${ }^{6}{ }^{\mathbb{D}}$, Reza Mohammadinejad ${ }^{6, *}$, Anuj Kumar ${ }^{7, *}$ \\ and Vijay Kumar Thakur $8, * \mathbb{D}$ \\ 1 Department of Biotechnology, Institute of Science and High Technology and Environmental Sciences, \\ Graduate University of Advanced Technology, Kerman 7631818356, Iran; sh.shakeri@kgut.ac.ir \\ 2 Department of Basic Science, Faculty of Veterinary Medicine, University of Tabriz, Tabriz 5166616471, Iran; \\ dvm.milad73@yahoo.com \\ 3 Sabanci University Nanotechnology Research and Application Center (SUNUM), Tuzla 34956, Istanbul, \\ Turkey; alizarrabi@sabanciuniv.edu \\ 4 Department of Biology, Faculty of Sciences, University of Isfahan, Isfahan 81746, Iran; r.roghanian@sci.ui.ac.ir \\ 5 Neuroscience Research Center, Institute of Neuropharmacology, Kerman University of Medical Sciences, \\ Kerman 7619813159, Iran; elham_gh_afshar@yahoo.com \\ 6 Pharmaceutics Research Center, Institute of Neuropharmacology, Kerman University of Medical Sciences, \\ Kerman 7616911319, Iran; drpardakhti@yahoo.com \\ 7 School of Chemical Engineering, Yeungnam University, 280 Daehak-ro, Gyeongsan 38541, Korea \\ 8 Enhanced Composites and Structures Center, School of Aerospace, Transport and Manufacturing, \\ Cranfield University, Bedfordshire MK43 0AL, UK \\ * Correspondence: r.mohammadinejad@kmu.ac.ir (R.M.); anuj.budhera@gmail.com (A.K.); \\ Vijay.Kumar@cranfield.ac.uk (V.K.T.)
}

Received: 10 November 2019; Accepted: 6 January 2020; Published: 13 January 2020

\begin{abstract}
The blood-brain barrier (BBB) acts as a barrier to prevent the central nervous system (CNS) from damage by substances that originate from the blood circulation. The BBB limits drug penetration into the brain and is one of the major clinical obstacles to the treatment of CNS diseases. Nanotechnology-based delivery systems have been tested for overcoming this barrier and releasing related drugs into the brain matrix. In this review, nanoparticles (NPs) from simple to developed delivery systems are discussed for the delivery of a drug to the brain. This review particularly focuses on polymeric nanomaterials that have been used for CNS treatment. Polymeric NPs such as polylactide (PLA), poly (D, L-lactide-co-glycolide) (PLGA), poly ( $\varepsilon$-caprolactone) (PCL), poly (alkyl cyanoacrylate) (PACA), human serum albumin (HSA), gelatin, and chitosan are discussed in detail.
\end{abstract}

Keywords: blood-brain barrier (BBB); central nervous system (CNS); nanotechnology; drug delivery systems; polymeric nanoparticles; theranostics

\section{Introduction}

Central nervous system (CNS) disorders are among the most common and complex diseases known in humans [1,2]. The best known brain diseases include cancers, neurodegenerative disorders, HIV encephalopathy, and inflammatory diseases [3,4]. Most cancer-related deaths in patients below the age of 35 have been reported as arising from brain cancer [5-7]. The different kinds of brain tumors are neuroepithelial, meningeal, primary CNS lymphomas, tumors of the sellar region, and metastatic [8-10]. Alzheimer's (AD), Parkinson's (PD), multiple sclerosis (MS), Huntington's, and prion diseases are the main neurodegenerative diseases (NDDs) that affect the neuron cells in a detrimental way [11-14]. NDDs lead to the loss or death of neural cell function and have symptoms related to movement, 
memory, and dementia. There are some unsolved problems in the clinic about the treatment of brain diseases [15-17]. In the past decade, CNS disorders represented one of the largest markets for the development of new treatments. This market reached US\$75.3 billion in 2010 and $\$ 102.0$ billion in 2015 [18-21]. Fortune Business Insights, in a recent report entitled “The Neurodegenerative Diseases Drugs Market: Global Market Analysis, Insights and Forecast, 2019-2026," gives valuable predictions about the market. In 2018, the global market value was $\$ 35,497.3$ million and is expected to grow to $\$ 62,786.2$ million by 2026 [22].

\section{The Blood-Brain Barrier (BBB)}

The blood-brain barrier (BBB) has a special structure that separates the extracellular fluid of neurons from blood circulation [23-29]. Paul Ehrlich gave the first evidence for the presence of $\mathrm{BBB}$ in his research in 1885 [30]. The BBB functions as a barrier for the complete separation of blood circulation from the fluid inside of the CNS and protects nerve cells from damage by foreign substances and infections that originate from the blood [31]. In addition, the BBB prevents water-soluble molecules, proteins, peptides, genes, and antibiotics with a molecular weight of above 500Da from reaching the brain, although NPs of such molecular weights could pass through it owing to their aspect ratio and spatial geometry [32,33]. This special barrier is composed of different kinds of cells. Endothelial cells, pericytes, astrocytes, and microglia are incorporated in the 3D structure of the BBB [34]. Endothelial cells in the structure of BBB have different characteristics from their counterparts in the periphery, including a high content of mitochondrial cells and changed pinocytic activity. The tight junctions between the neighboring endothelial cells are complex and formed by several transmembrane proteins. Pericytes are located at the inner brain membrane and are covered by basal lamina and proteins $[35,36]$. Astrocytes and their endfeet have been attached to the walls of capillaries and help steady the capillary structure [37]. The BBB is the main problem in the treatment of CNS diseases. Therefore, overcoming this barrier is the most critical area of research for CNS disease therapy [38,39].

There are two current strategies: paracellular and transcellular transport for passive or active crossing of the BBB, respectively [40]. Temporary disruption of the BBB, transcytosis, and nanoplatforms facilitate the delivery of molecules into the CNS [41]. Molecules use active efflux transporters, carrier-mediated transporters, and receptor-mediated transporters to cross the BBB. Nanoconjugation of ligands targeting endothelial cell surface receptors facilitates the endocytosis of nanocarriers. Iron-transferrin, insulin, metabolic nutrient transporters, low-density lipoprotein (LDL) cholesterol, nicotinic acetylcholine (nAchR), and integrin are the most explored receptors for transporting drugs across the BBB [42].

\section{Nano-Scale Drug Delivery to the Brain}

In recent years, a wide variety of studies have been performed in the field of drug delivery into the brain [43-46]. However, the BBB is a barrier to the successful delivery of drugs to the CNS since only a small number of molecules can cross the BBB [47]. Almost all (>98\%) small molecules can cross the BBB, whereas high molecular weight drugs such as proteins, peptides, monoclonal antibodies, and genes are not able to penetrate through the BBB and access the CNS [48-50]. Hence, novel technologies and delivery systems are needed to overcome this barrier and release the drugs into the brain matrix. Nanotechnology-based drug delivery systems are a powerful method for drug transport into the brain $[40,51,52]$. A well-known candidate for CNS targeted delivery of drugs is colloidal-based particulate systems [53-55]. NPs are used in the form of nanospheres as well as nanocapsules, and the drug is entrapped inside the matrix or attached to the surface [56,57]. Nanomaterials penetrate small capillaries because of their size; cells absorb them and the drug will be released into their compartment or cytoplasm. Sustained drug release at the targeted site is one of the advantages of NPs that are prepared with biodegradable materials [58-60]. NPs made of polymeric materials are solid particles ranging in size from 1 to $100 \mathrm{~nm}$ in at least one dimension. They are nontoxic, nonimmunogenic, and stable in the blood if they are appropriately surface engineered with proper ligands $[61,62]$. 
The drugs stay inside or at the surface of biodegradable NPs and will be released in a tunable manner at a specific site in the body. In this way, the targeted delivery of drugs will enhance therapeutic efficiency and reduce drug toxicity and side effects $[42,63]$. Reduction of adverse side effects and improvements in the bioavailability of drugs with a short half-life are other potential benefits of NPs-based drug-delivery systems [64,65]. Nanotechnology can be applied for the delivery of drugs to the brain for the treatment of brain-related diseases. For instance, several drugs such as growth factors and neuropeptides cannot cross the BBB and so are ineffective when administered intravenously (IV) [66,67]. Therefore, numerous efforts have been focused on the use of NPs for the delivery of drugs into the brain [18].

\section{Development of the Nanoparticulate Systems: From Simple to Targeted Generations}

Long-time circulation in the bloodstream is one of the most important characteristics of NPs after IV administration [68,69]. The reticuloendothelial system (RES) is an active agent in the removal of the first generation of NPs (without the capability of escape from RES) from the blood circulation. Some characteristics of NPs such as size and surface charge help them to escape from clearance property of RES and endure more time in circulation [70]. Moreover, the particles' size and charge could affect their cellular uptake and cytotoxicity, so that particles with a size of less than $500 \mathrm{~nm}$ and a positive charge are more suitable for cell uptake. In other words, particles $<200 \mathrm{~nm}$ are preferred for systemic applications. It is important to remark that particles smaller than $5 \mathrm{~nm}$ are also not suitable since they may be removed from the circulation by renal excretion. Moreover, they are hazardous since they can directly affect the important biological macromolecules of the nucleus (DNA and RNA). On the other hand, positively charged particles also facilitate interactions with negatively charged cell membranes, along with increasing the cytotoxicity. These positively charged particles can also improve the interaction of NPs with other types of biological components, such as proteins, that restrict their circulation time, while particles with a neutral or negative charge have longer circulation times [71-73].

The surface modification of NPs with different molecules such as polyethylene glycol (PEG) is a promising strategy for increasing the half-life and persistence in the bloodstream (second generation of NPs). An external surface layer of hydrophilic PEG chains around the hydrophobic polymeric matrix camouflages particles from recognition by RES and provides a long plasma residence time [74]. In addition to the long-time circulation, the good affinity of NPs for the targeted tissue is another important factor in drug delivery [75]. It has been shown that PEGylated NPs have a low affinity to the brain [74]. The first attempt at the delivery of the drug to the brain was made by Kreuter et al. [76]. They used polysorbate 80-coated poly (butyl cyanoacrylate) (PBCA) NPs for the delivery of dalargin into the CNS (third generation of NPs). This kind of NP has a good affinity to the brain in addition to long-time circulation, and several drugs have been successfully delivered into the brain by this system [77-79]. Various types of nanosystems have been evaluated for drug delivery to the brain [80-82]. Receptor-mediated transporter systems are modern examples of these NPs [83-85]. The effective delivery of drugs to the specific target site (e.g., the brain) is achieved by the ligand-receptor mechanism. The presence of ligands on the surface of drug-loaded NPs can deliver the carrier system to the target sites with specific receptors [41,86-89]. For instance, some ligands such as transferrin (Tf), Apolipoprotein (Apo) E, B, A, and antibodies (Tf receptor or OX26) on the surface of NPs have been shown to pass through the BBB and allow targeted delivery of carriers into the brain parenchyma via receptor-mediated endocytosis [90-96]. For example, PEGylated albumin or chitosan (CS) NPs coupled with OX-26 were proposed as a potential candidate for targeted brain delivery [97,98]. The main mechanism for the delivery of these NPs through the BBB is receptor-mediated transport endocytosis.

\section{Polymeric Nanoparticles for Brain Disease Theranostics}

The therapeutic benefits of various water-soluble/insoluble drugs and bioactive agents, such as solubility, bioavailability, and retention time, are promoted by the frequent use of biodegradable polymer-based NPs [99,100]. A wide range of polymeric biomaterials are used as a matrix for drug delivery nanosystems [101]. Polymeric biomaterials include synthetic and natural ones, 
and their hybrid polymers. For the successful application of these polymeric systems in medicine and pharmaceuticals, one must consider the biocompatibility, biodegradability, and nontoxic, nonimmunogenic, and noncarcinogenic characteristics of these materials [102]. Herein, we have discussed synthetic and natural polymers for application in the field of nanotechnology-based delivery systems to the brain (Figure 1) (Table 1).

Table 1. Some selected polymeric NPs for the delivery of drugs to the brain.

\begin{tabular}{|c|c|c|c|}
\hline Polymers & $\begin{array}{l}\text { Model Drug/Other } \\
\text { Molecules }\end{array}$ & Remarks & References \\
\hline PLA & Neurotoxin-I NT-I & $\begin{array}{l}\text { Intranasal (IN) administration of } \\
\text { NT-I-PLA is more effective than IV } \\
\text { administration }\end{array}$ & [103] \\
\hline $\begin{array}{l}\text { Polylactic acid-co- } \\
\text { hyperbranched polyglycerol } \\
\text { modified with adenosine } \\
\text { (PLA-HPG-Ad) }\end{array}$ & Camptothecin (CPT) & $\begin{array}{l}\text { Increased BBB uptake after } \\
\text { IV injection }\end{array}$ & [104] \\
\hline PLA & $\begin{array}{l}\text { Thyrotropin-releasing } \\
\text { hormone (TRH) }\end{array}$ & Effective IN administration & [105] \\
\hline PLA-TPGS & $\mathrm{Tf}$ & $\begin{array}{c}\text { More effective compared to NPs } \\
\text { without Tf }\end{array}$ & [106] \\
\hline PLA-PEG-CPPs & NT-I & $\begin{array}{l}\text { High concentration of drug in the } \\
\text { brain through IN administration }\end{array}$ & [107] \\
\hline PLA & Neuropeptide & $\begin{array}{l}\text { High drug delivery in IN } \\
\text { administration }\end{array}$ & [108] \\
\hline PLG-PEG-H102 & $\begin{array}{l}\text { H102 peptide } \\
\text { (HKQLPFFEED) }\end{array}$ & $\begin{array}{l}\text { High uptake and biocompatibility, } \\
\text { and high concentration of } \\
\text { coumarin- } 6 \text { in the brain following } \\
\text { IV administration }\end{array}$ & [109] \\
\hline PLA-mPEG-Lf & $\mathrm{Tf}$ & Reduced toxicity & [110] \\
\hline PLA-MPS-LDLR & Resveratrol & $\begin{array}{l}\text { Increased the migration of NPs } \\
\text { through the BBB }\end{array}$ & [111] \\
\hline PLGA-CS, P80, and P188 & - & $\begin{array}{l}\text { Prolonged circulation in the blood, } \\
\text { high cellular uptake }\end{array}$ & [112] \\
\hline $\begin{array}{l}\text { PLGA-PVA or HSA/P80 or } \\
\text { P188 }\end{array}$ & $\begin{array}{c}\text { Doxorubicin (DOX) and } \\
\text { loperamide }\end{array}$ & $\begin{array}{c}\text { Crossed the BBB and released the } \\
\text { drug at a specific site }\end{array}$ & [113] \\
\hline Tween 80-PLGA & Estradiol & $\begin{array}{l}\text { High level of the drug in the brain } \\
\text { after oral administration }\end{array}$ & [114] \\
\hline $\begin{array}{l}\text { Trimethylated chitosan } \\
\text { (TMC)-PLGA }\end{array}$ & Coenzyme Q10 & $\begin{array}{l}\text { Low toxicity and good penetration } \\
\text { into the brain matrix }\end{array}$ & [115] \\
\hline PLGA-PEG & Pep TGN & $\begin{array}{l}\text { High accumulation of NPs in the } \\
\text { brain after IV injection }\end{array}$ & [116] \\
\hline PEGylated-PLGA & Memantine & $\begin{array}{c}\text { Decreased amyloid-beta }(\mathrm{A} \beta) \\
\text { plaques and related inflammation } \\
\text { characteristics }\end{array}$ & [117] \\
\hline mPEG-PLGA & Schisantherin A & $\begin{array}{l}\text { Improved oral bioavailability, } \\
\text { increased brain uptake, } \\
\text { and enhanced the bioactivity of } \\
\text { this drug }\end{array}$ & [118] \\
\hline $\begin{array}{l}\text { Rabies virus glycoprotein } \\
\text { 29-modified } \\
\text { deferoxamine-loaded PLGA }\end{array}$ & Deferoxamine & $\begin{array}{c}\text { Significantly decreased } \\
\text { dopaminergic neuron damage }\end{array}$ & [26] \\
\hline $\begin{array}{l}\text { BBB-penetrating } \\
\text { peptide-PLGA }\end{array}$ & $\begin{array}{l}\mathrm{A} \beta \text { generation inhibitor } \\
\text { and curcumin }\end{array}$ & $\begin{array}{l}\text { Increased activity of superoxide } \\
\text { dismutase (SOD) and synapse } \\
\text { numbers in the AD mouse brains }\end{array}$ & [119] \\
\hline
\end{tabular}


Table 1. Cont.

\begin{tabular}{|c|c|c|c|}
\hline Polymers & $\begin{array}{l}\text { Model Drug/Other } \\
\text { Molecules }\end{array}$ & Remarks & References \\
\hline PLGA-anti-EPHA3 & $\begin{array}{l}\text { Temozolomide } \\
\text { (TMZ) }\end{array}$ & $\begin{array}{c}\text { Significantly taken up by } \\
\text { glioblastoma cells, remarkably } \\
\text { increased apoptosis }\end{array}$ & [120] \\
\hline Lf-PLGA-PEG & Shikonin, lactoferrin & $\begin{array}{c}\text { Great uptake and distribution in } \\
\text { the brain }\end{array}$ & [121] \\
\hline PLGA & Ropinirole (RP) & $\begin{array}{l}\text { Reverted PD-like symptoms of } \\
\text { neurodegeneration in the } \\
\text { animal model }\end{array}$ & [122] \\
\hline PLGA & Curcumin & $\begin{array}{l}\text { Decreased tumor size and } \\
\text { increased survival of } \\
\text { animal model }\end{array}$ & [123] \\
\hline PLGA & Paclitaxel & Increased treatment of glioma & [124] \\
\hline PLGA & L-carnitine & $\begin{array}{l}\text { Significantly crossed the BBB, } \\
\text { great antiglioma efficacy }\end{array}$ & [125] \\
\hline $\begin{array}{c}\text { Poly(N-isopropyl } \\
\text { acrylamide)-b-poly(caprolactone) } \\
\text { (PN-co-PCL) }\end{array}$ & Clonazepam & Prevented fast release of the drug & [126] \\
\hline PCL-PEG & $\begin{array}{c}\text { 5-iodo } 2 \text { ' deoxyuridine } \\
\text { (IUdR) }\end{array}$ & $\begin{array}{l}\text { High toxicity against } \\
\text { glioblastoma cells }\end{array}$ & [127] \\
\hline $\begin{array}{l}\text { Poly ( } \varepsilon \text {-caprolactone diol)-based } \\
\text { polyurethane (PCL-Diol-b-PU) }\end{array}$ & CS and TMZ & $\begin{array}{l}\text { Significantly decreased the cell } \\
\text { viability and survival of } \\
\text { glioblastoma cells }\end{array}$ & [128] \\
\hline $\begin{array}{l}\text { Lipid polymer nanoparticles } \\
\text { (LPN) }\end{array}$ & $\begin{array}{l}\text { Pemetrexed- and miR- } 21 \\
\text { antisense oligonucleotide }\end{array}$ & $\begin{array}{l}\text { Increased the cellular uptake and } \\
\text { gradually released of pemetrexed }\end{array}$ & [129] \\
\hline PCL & Eugenol encapsulated CS & $\begin{array}{l}\text { Increased bioavailability for the } \\
\text { treatment of cerebral ischemia }\end{array}$ & [130] \\
\hline PCL-Diol-b-PU/gold & TMZ & $\begin{array}{l}\text { Decreased viability and survival } \\
\text { of glioblastoma cells }\end{array}$ & [131] \\
\hline PEGylated PCL & Docetaxel & Effective cytotoxicity & [132] \\
\hline Polysorbate 80-coated PBCA & Tarcrine & $\begin{array}{l}\text { Increased drug concentration in } \\
\text { the brain }\end{array}$ & [133] \\
\hline PBCA-P80 or P188 & DOX & Considerable antitumor effects & [134] \\
\hline PBCA-Apo E3 & Curcumin & $\begin{array}{l}\text { Increased antiapoptotic activity of } \\
\text { Apo E3- curcumin-PBCA NPs }\end{array}$ & [135] \\
\hline PBCA-P80 & $\begin{array}{l}\text { Nerve growth factor } \\
\text { (NGF) }\end{array}$ & $\begin{array}{c}\text { Moderation in symptoms of } \\
\text { oligokinesia }\end{array}$ & [136] \\
\hline $\begin{array}{c}\text { PBCA-P20,40,60,80,184,188,388,407, } \\
\text { and } 908\end{array}$ & Dalargin & $\begin{array}{l}\text { The surfactant polysorbate } 80 \\
\text { enabled the highest induction of } \\
\text { analgesia at both dosages } \\
\text { of dalargin }\end{array}$ & [137] \\
\hline PBCA-P80 & Dalargin & $\begin{array}{l}\text { Efficient delivery of drugs into } \\
\text { the brain }\end{array}$ & [138] \\
\hline $\begin{array}{l}\text { P(HDCA-co-RCA-co-MePEGCA) } \\
\text { and }{ }^{14} \mathrm{C}-\mathrm{P}(\text { HDCA-co-MePEGCA) }\end{array}$ & Anti-A $\beta 1-42$ & $\begin{array}{l}\text { Completed correction of the } \\
\text { memory defect in an experimental } \\
\text { model of AD }\end{array}$ & [139] \\
\hline $\begin{array}{l}\text { PLGA functionalized with } \\
\text { OX26-type monoclonal antibody }\end{array}$ & TMZ & Cytotoxicity improvement of TMZ & [140] \\
\hline PLGA-b-PEG-ascorbic acid & Galantamine (GLM) & $\begin{array}{l}\text { High biodistribution, therapeutic, } \\
\text { and sustained action of the drug }\end{array}$ & [141] \\
\hline
\end{tabular}


Table 1. Cont.

\begin{tabular}{|c|c|c|c|}
\hline Polymers & $\begin{array}{l}\text { Model Drug/Other } \\
\text { Molecules }\end{array}$ & Remarks & References \\
\hline $\begin{array}{c}\text { 1,2-distearoyl-sn-glycero-3- } \\
\text { phosphoethanolamine-N- } \\
\text { [amino(polyethylene glycol)-2000 } \\
\text { (DSPE-PEG2000) }\end{array}$ & $\begin{array}{l}\text { Poly(benzodithiophene-alt- } \\
\text { benzobisthiadiazole) }\end{array}$ & $\begin{array}{l}\text { Efficient near-infrared (NIR) II PA } \\
\text { imaging of orthotropic brain tumor }\end{array}$ & [142] \\
\hline $\begin{array}{l}\text { Polyacrylamide (PAAM)-cardiolipin } \\
\text { (CL)- PLGA grafted with 83-14 } \\
\text { monoclonal antibody (MAb) }\end{array}$ & $\begin{array}{l}\text { Curcumin (CUR) and } \\
\text { Rosmarinic acid (RA) }\end{array}$ & $\begin{array}{l}\text { Permeated the BBB and reduced the } \\
\text { fibrillar } A \beta \text {-induced neurotoxicity }\end{array}$ & [143] \\
\hline HSA-Tf or TfR mAbs & Loperamide & $\begin{array}{l}\text { Loperamide delivery across the BBB } \\
\text { induced antinociceptive } \\
\text { (analgesic) effects }\end{array}$ & [92] \\
\hline $\begin{array}{l}\text { HSA-insulin or anti-insulin receptor } \\
\text { monoclonal antibody }\end{array}$ & Loperamide & $\begin{array}{l}\text { Induced significant antinociceptive } \\
\text { effects in the tail-flick test }\end{array}$ & [144] \\
\hline HSA & Paclitaxel & $\begin{array}{l}\text { Great uptake by brain capillary } \\
\text { endothelial cells and U87 cells }\end{array}$ & [145] \\
\hline Serum albumin & R-flurbiprofen & $\begin{array}{l}\text { Higher brain to-plasma ratio profile, } \\
\text { amelioration of mitochondrial } \\
\text { dysfunction in } \mathrm{AD}\end{array}$ & [146] \\
\hline BSA & $\begin{array}{l}\text { Borneol, muscone, } \\
\text { and menthol }\end{array}$ & $\begin{array}{l}\text { The biocompatible carriers } \\
\text { efficiently penetrate the BBB and are } \\
\text { captured by cells }\end{array}$ & [147] \\
\hline Gelatin (GE)-mannan & $\begin{array}{l}\text { Anti-HIV drug (hydrophilic } \\
\text { didanosine) }\end{array}$ & $\begin{array}{c}\text { Increased brain concentration of } \\
\text { the drug }\end{array}$ & [148] \\
\hline GE-siloxane-SynB & rhodamine B isothiocyanate & $\begin{array}{l}\text { The biocompatible nanocomplexes } \\
\text { were efficiently taken up by brain } \\
\text { capillary endothelial cells }\end{array}$ & [149] \\
\hline GE-cardamom extract & & Cytotoxic effects on U87MG cells & [150] \\
\hline CS & Estradiol & $\begin{array}{l}\text { Efficient delivery of estradiol to the } \\
\text { cerebrospinal fluid (CSF) through } \\
\text { IN administration }\end{array}$ & [151] \\
\hline CS-PEG-biotin-avidin/OX26 & $\begin{array}{l}\text { Anticaspase peptide } \\
\text { Z-DEVD-FMK }\end{array}$ & $\begin{array}{l}\text { Z-DEVD-FMK delivery to the brain, } \\
\text { outside of the } \\
\text { intravascular compartment }\end{array}$ & [152] \\
\hline CS- $\beta$-cyclodextrin & Estradiol & $\begin{array}{l}\text { Significantly increased the amount } \\
\text { of estradiol in the CSF }\end{array}$ & [153] \\
\hline CS & Dopamine & $\begin{array}{l}\text { Enhanced brain delivery } \\
\text { of dopamine }\end{array}$ & [154] \\
\hline CS & Lactoferrin & Cytoplasmic allocation of the NPs & [155] \\
\hline Antibody-modified CS & siRNA & $\begin{array}{l}\text { Showing their efficiency in } \\
\text { inhibiting HIV replication } \\
\text { in astrocytes }\end{array}$ & [156] \\
\hline CS-iron oxide & DOX & $\begin{array}{l}\text { High uptake of NPs by C6 glioma } \\
\text { cells, showing their application in } \\
\text { the diagnosis of glioblastoma }\end{array}$ & [157] \\
\hline $\begin{array}{l}\text { CS hydrochloride/hyaluronic } \\
\text { acid/PEG }\end{array}$ & Lactoferrin & The NPs can penetrate the BBB & [158] \\
\hline CS-1, 3-glucan & Paclitaxel & $\begin{array}{l}\text { Potential therapeutic options } \\
\text { are demonstrated }\end{array}$ & {$[159,160]$} \\
\hline CS & $\begin{array}{c}\text { Pramipexole } \\
\text { dihydrochloride (P) }\end{array}$ & $\begin{array}{l}\text { Superior in vivo activity for brain } \\
\text { targeted delivery in } \\
\text { Parkinson's disease }\end{array}$ & [161] \\
\hline CS-based hydrogel & $\begin{array}{l}\text { Methotrexate } \\
\quad \text { (MTX) }\end{array}$ & $\begin{array}{l}\text { Facilitated MTX passage by } \\
\text { providing a higher concentration of } \\
\text { the drug in contact with the BBB }\end{array}$ & [162] \\
\hline
\end{tabular}




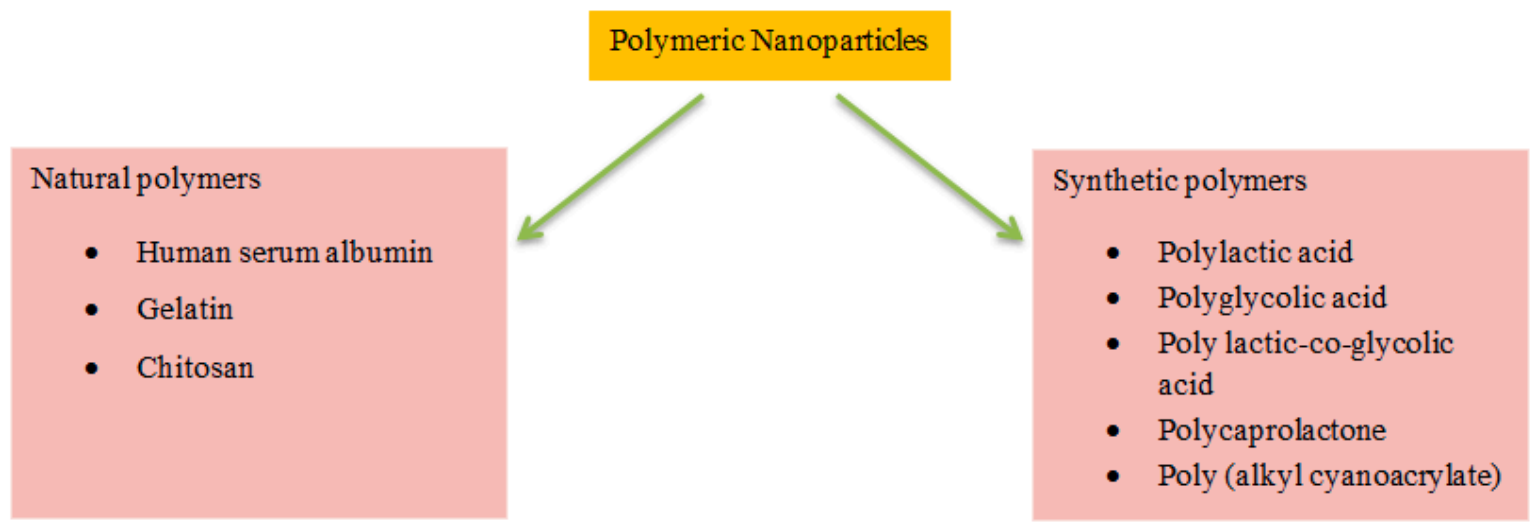

Figure 1. Selected polymeric NPs for the delivery of drugs to the brain.

\subsection{Synthetic Polymers}

\subsubsection{Polyesters}

Synthetic polymers have been widely used for the delivery of bioactive agents and drugs [44,163-172]. Among them, polyesters have great potential because of their biocompatibility and biodegradability. They are toxicologically safe and their monomers, as well as by-products, are eliminated by the metabolic pathways of the human body [173]. Polylactic acid (PLA), polyglycolic acid (PGA), and PLGA have been widely used in medicine and pharmaceuticals [174]. PLA and PLGA have been approved by the FDA for clinical uses [112]. These polymers degrade in the human body without any induction of inflammation or immune reactions [175]. They have been applied for the fabrication of biodegradable medical devices such as scaffolds and drug-loaded NPs or implants [176].

\subsubsection{PLA}

PLA is a biocompatible polymer and biodegradable in the human body that degrades into its monomeric units [177]. The monomer of lactic acid is a safe and natural intermediate in carbohydrate metabolism. Cheng et al. [103] studied the delivery of neurotoxin-I (NT-I) using PLA NPs. The authors used PLA instead of PBCA to prevent the toxicity of the by-products. The level of NT-I was found to increase in the brain after IN or intravascular (IV) administration of NT-I-PLA NPs. Results have demonstrated that IN administration of NT-I-PLA NPs was more effective than intravascular administration. Kubek et al. [105] used thyrotropin-releasing hormone (TRH) for loading into the PLA NPs for the IN administration of seizure. Although the results were not as expected, the authors believe that IN administration of biodegradable NPs can be effective in the treatment of seizures. Hu et al. [178] studied the use of lactoferrin (Lf)-conjugated PEG-PLA NPs to deliver a fluorescent dye (coumarin-6) into the mouse brain. An IV injection of Lf-PEG-PLA NPs demonstrated that the NPs' entrance into the brain was increased 3-fold by coumarin-6 in the mouse brain compared to NPs without Lf. The authors suggested that the Lf-PEG-PLA NPs system can provide a novel system for brain drug delivery, especially targeting peptides, proteins, and genes. Tf was another ligand used by Gan and Feng [106]. They fabricated Tf-conjugated NPs of PLA-d- $\alpha$-Tocopheryl polyethylene glycol succinate (PLA-TPGS) diblock copolymer for the delivery of imaging and therapeutic agents. The results showed the higher effectiveness of Tf-decorated NPs for the delivery of agents across the BBB. Cell-penetrating peptides (CPPs) with a low content of basic amino acids were reported as good candidates for the functionalization of PEG-PLA NPs and drug delivery to the brain [107]. Increased accumulation of functionalized NPs was observed in the brain. Song et al. prepared polylactic acid NPs to evaluate their efficiency in brain delivery (Figure 2) [108]. They have shown that the surface properties of NPs were associated with their cellular distribution, and used them in in vitro and in vivo studies to test the idea. Overall, it was concluded that PLA NPs are potential candidates for the delivery of therapeutics into the brain due to their low toxicity and high uptake by brain cells. 

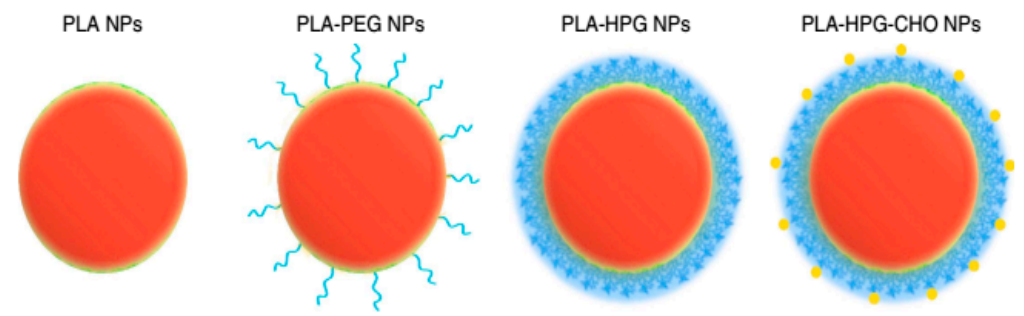

b
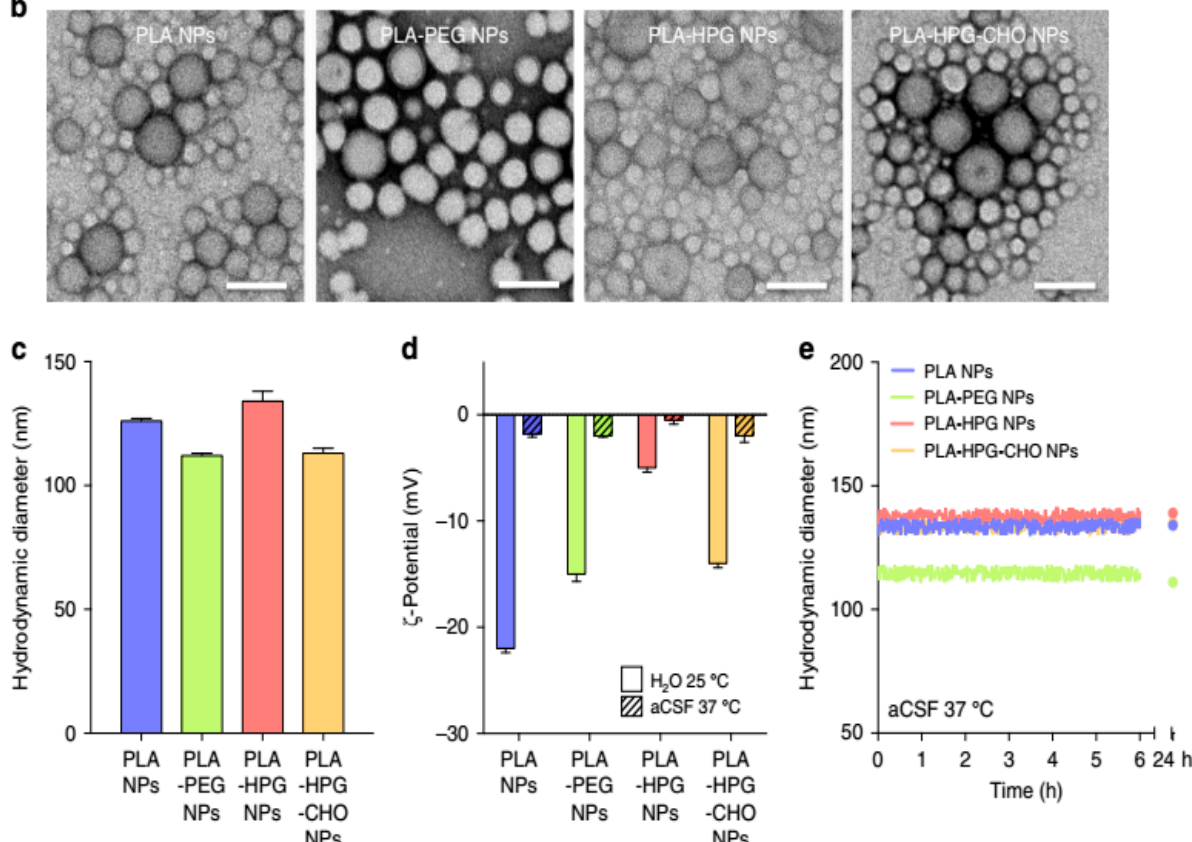

Figure 2. (a) Schematic representation of PLA-based NPs having different coating materials. (b) Population and morphology of NPs using TEM (scale bar $=100 \mathrm{~nm}$ ). (c) Characterization of NPs for hydrodynamic diameters using dynamic light scattering (d), zeta potential using laser doppler anemometry (e), and analysis of particle size (in CSF at $37^{\circ} \mathrm{C}$ ) is observed as stable and no measurable aggregation was observed up to $24 \mathrm{~h}$. Reproduced with permission from Song, E.; Gaudin, A.; King, A.R.; Seo, Y.E.; Suh, H.W.; Deng, Y.; Cui, J.; Tietjen, G.T.; Huttner, A.; Saltzman, W.M. Surface chemistry governs cellular tropism of nanoparticles in the brain. Nat. Commun. 2017 [108].

Zheng et al. designed H102-loaded PEG-PLG NPs for efficient delivery into the brain in the case of AD [109]. In this case, some NPs are able to cross the BBB and are taken up by caveolae-mediated endocytosis. Interestingly, H102-loaded PEG-PLG NPs have shown excellent biocompatibility and, simultaneously, good therapeutic efficiency in reducing $\mathrm{A} \beta$ plaques, enhancing $\mathrm{A} \beta$-degrading enzymes, decreasing tau protein phosphorylation, protecting synapses, and promoting spatial learning and memory. Pan et al. investigated the delivery of $\alpha$-asarone into the brain by lactoferrin-modified mPEG-PLA NPs [110]. They prepared NPs using premix membrane emulsification and used IN administration. These NPs efficiently delivered $\alpha$-asarone into the brain and displayed good permeability and bioavailability. Interestingly, it was found that lactoferrin moiety is involved in increasing the efficacy of brain targeting, reducing liver accumulation, and reducing the level of toxicity on nasal mucosal cilia and epithelial cells. Shen et al. prepared low-density lipoprotein receptor (LDLR) peptide-conjugated polylactic acid (PLA)-coated mesoporous silica NPs for the delivery of resveratrol into the brain [111]. PLA coating was used as an occlusion for resveratrol burst release and they also used reactive oxygen species (ROS) to facilitate PLA degradation and induce drug release. It was found that LDLR ligand peptides increase the migration of NPs through the BBB and remarkably decrease the stimulation of microglial cells by phorbol myristate acetate or lipopolysaccharide, leading to the efficiency of these NPs in treating oxidative stress in the CNS. 
Wang and co-workers synthesized cationic lipid assisted PEG-PLA NPs to prevent microglial neurotoxicity [179]. They prepared NPs using a double-emulsion solvent evaporation technique and then loaded complement component C3-siRNA on NPs to inhibit microglial neurotoxicity after cerebral ischemia/reperfusion (I/R) injury. It was found that these NPs potentially penetrate the BBB and remarkably reduce the expression of $\mathrm{C} 3$ in microglial cells as well as simultaneously decrease the number of inflammatory cells and pro-inflammatory factors in the penumbra, resulting in efficient improvement of the brain I/R injury. Zhu et al. designed tumor-specific protease-activated cell-penetrating peptide (ACPP)-conjugated micelles for treating brain gliomas [180]. In vitro and in vivo studies demonstrated good uptake and intracellular drug release of micelles. Also, these micelles were found to efficiently penetrate the BBB and, using ACPP, promoted the survival of mice bearing gliomas. Furthermore, these micelles had lower toxicity.

\subsubsection{PLGA}

Various studies have been performed to fabricate PLGA NPs and scaffolds [181]. The biodegradability, biocompatibility, and long-lasting and sustained release properties of PLGA make it a suitable polymer for biomedical and pharmaceutical applications $[178,182]$. The polymer degradation and drug-releasing profile can be affected by changes in molecular weight and the molar ratio of lactic acid to glycolic acid [112]. Both monomers are consumed and eliminated during the normal metabolism of the cells [183]. Biodegradable delivery systems based on the PLGA polymer have been used in the imaging, diagnostics, and treatment of diseases [184-187]. Entrapment of various types of drugs such as proteins, peptides, genes, and anticancer drugs has been performed in PLGA NPs [188-191]. Protein and peptide drugs are susceptible to high temperature or acidic environments. Long-term exposure of proteins and peptides to the acidic by-products of PLGA can decrease the stability and bioavailability after polymer degradation [192]. So, it is important to determine the physicochemical characteristics of proteins and peptides.

PLGA NPs have been investigated for the treatment of brain diseases. Tahara et al. [112] studied different surface-modified PLGA NPs for delivery to the brain. The authors used CS, polysorbate 80 (P80), and poloxamer 188 (P188) as surface modifier agents in their studies. NPs were prepared by the emulsion solvent diffusion method. After carotid artery injection, P80-PLGA NPs were found to exhibit prolonged circulation in the blood compared to the other NPs, and their concentration in the brain was increased. In addition, the cellular uptake of CS-PLGA NPs was higher due to electrostatic interaction with the cell membrane. Budhian et al. [193] showed that hydroxyl-terminated PLGA NPs can release haloperidol over a long period as compared to methyl-terminated PLGA NPs. Haloperidol is an antipsychotic drug used for schizophrenia therapy. Gelperina et al. [113] have used surfactant-coated PLGA NPs for the delivery of DOX and loperamide to the brain. In this study, polyvinyl alcohol (PVA) and human serum albumin (HSA) were used as stabilizers, while P80 and P188 were used as coating surfactants for the formulation of PLGA NPs. Results showed that DOX-PLGA/PVA+P188 NPs were most effective and had a high antitumor effect. DOX-PLGA/HSA+P188 NPs also exhibited a high antitumor effect and produced long-term remission in the tested animals. The effect of Lop-PLGA/PVA+P80 and Lop-PLGA/HSA+P188 NPs was also considerable. The effect of the surfactants on the efficiency of the HSA-stabilized particles was less than that of particles stabilized by PVA. The high antitumor effect against glioblastomas, as well as considerable analgesia, revealed that these NP systems can cross the BBB and release the drug at a specific site. Similar results were also observed by Chen et al. [118]. Block copolymers were also used for the preparation of NPs [194]. Loperamide-loaded PLGA-PEG-PLGA NPs with a surface modified by poloxamer 188 or polysorbate 80 were used for in vitro BBB penetration. Mittal et al. [114] studied Tween 80-coated PLGA NPs for the delivery of estradiol to the brain upon oral administration in a rat model of AD. Results showed that a high level of estradiol was detectable in the brain after oral administration. In addition, the suppression of A $\beta 42$ expression by estradiol showed that Tween 80-PLGA NPs could deliver estradiol to the brain by the oral administration route. Surface modification of PLGA NPs with TMC was carried out by 
Wang et al. [115]. Coenzyme Q10-loaded TMC/PLGA NPs were found to improve memory impairment after injection. In addition, the NPs were found to exhibit low toxicity and good penetration into the brain matrix. Pep TGN, a novel 12 amino acid peptide, was used as a ligand that was attached to the surfaces of PEG-PLGA NPs for targeting the brain. High accumulation of NPs was observed in the brain after IV injection [123]. Work was done by other researchers to prepare and fabricate NPs using PLGA polymers. These polymeric NPs can target brain cancer and other diseases [195,196]. Sanchez-Lopez et al. developed PLGA PEGylated NPs for the delivery of memantine in AD [117]. MTT tests showed that these NPs are safe for brain cell lines (bEnd.3 and astrocytes) and PLGA PEGylated NPs could penetrate the BBB. It was found that these NPs containing memantine decrease $\mathrm{A} \beta$ plaques and related inflammation characteristics of AD. Chen et al. designed small mPEG-PLGA NPs for the delivery of schisantherin A in PD (Figure 3) [118]. It was demonstrated that these NPs promote the delivery of schisantherin A into the brain, improve the oral bioavailability, increase the brain uptake, and enhance the bioactivity of this drug.

A

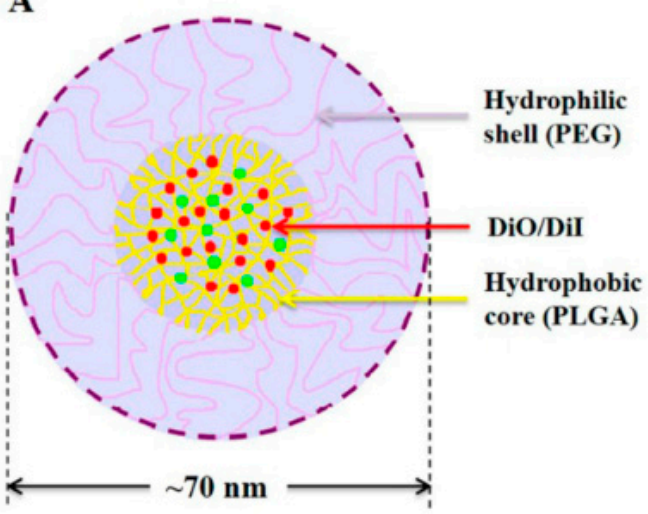

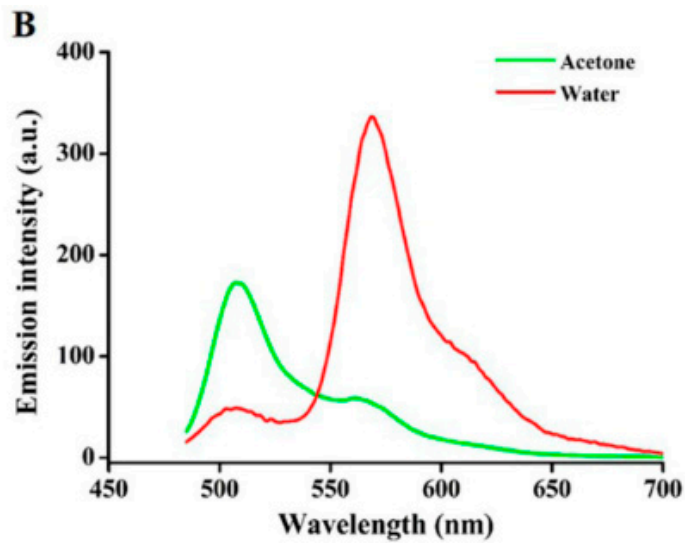

Figure 3. (A) Schematic diagram of DiO/DiI (1:1) NPs with each at $0.5 \%$ weight ratio of the polymer and (B) fluorescence spectra of DiO/DiI NPs with 10-fold dilution in water (red) and acetone (green). Reproduced with permission from Chen, T.; Li, C.; Li, Y.; Yi, X.; Wang, R.; Lee, S.M.Y.; Zheng, Y. Small-sized mPEG-PLGA nanoparticles of Schisantherin A with sustained release for enhanced brain uptake and anti-parkinsonian activity. ACS Appl. Mater. Interfaces 2017 [118].

Huang et al. synthesized PLGA NPs with a BBB-penetrating peptide for the co-delivery of $A \beta$ generation inhibitor and curcumin in AD mice [119]. Overall, they found that these NPs were associated with a reduced level of Ab, ROS, TNF-a, and IL-6, and increased activity of superoxide dismutase (SOD) and synapse numbers in AD mouse brains, leading to their potential therapeutic use in AD. Chu et al. prepared TMZ-loaded PLGA NPs functionalized with anti-EPHA3 for targeting glioblastomas [120]. It was demonstrated that these NPs are significantly taken up by glioblastoma cells and also remarkably increase the apoptosis in tumor cells. Li et al. prepared lactoferrin-functionalized PEG-PLGA NPs for the delivery of shikonin and the treatment of gliomas [121]. A coating of lactoferrin was used to promote penetration through the BBB, and in vitro and in vivo experiments showed the great uptake and distribution of NPs in the brain, resulting in their effectiveness in the treatment of glioblastomas. Orunoglu et al. synthesized curcumin-loaded PLGA NPs for targeting gliomas [123]. They showed the decreased tumor size and increased survival of mice treated with these NPs. Zou et al. investigated the effectiveness of paclitaxel-loaded PLGA NPs in targeting brain tumor-associated macrophages [124]. Their results demonstrated the beneficial effects of these NPs in the treatment of gliomas. Also, it has been shown that brain- and brain tumor-penetrating disulfiram NPs were cytotoxic to glioma cells and intracranial xenografts [197]. Kou et al. prepared L-carnitine-conjugated PLGA NPs for targeting glioma cells [125]. These NPs were found to significantly cross the BBB and showed great antiglioma efficacy. Chai et al. synthesized efficient functionalized cell membrane-coated NPs with neurotoxin-derived peptides for brain drug delivery [198]. 


\subsubsection{Poly ( $\varepsilon$-caprolactone) (PCL)}

Poly ( $\varepsilon$-caprolactone) (PCL) is a biodegradable polyester that is widely applied to promote toughness and enhance the flexibility of various materials such as PLA. Moreover, PCL, as a common polymer for electrospinning, has been used extensively for cell culture scaffolds [199-201]. PCL degrades slower than PLA and therefore is suitable to fabricate scaffolds and NPs for the long-term and sustained release of pharmaceutical agents [202,203]. Changyong et al. [126] used Poly (N-isopropyl acrylamide)-b-poly(3-caprolactone) (PNPCL) block copolymers as a thermosensitive nanosystem for the delivery of clonazepam into the brain. Results showed that Poly ( $\mathrm{N}$-isopropyl acrylamide) as part of a copolymer covers the surface of NPs in a layer and prevents the fast release of the drug. The role of clonazepam in the brain is the enhancement of the effects of GABA; it thereby decreases or stops specific signaling in the nerves. Rezaie et al. investigated the effect of hyperthermia and ionizing radiation on the cytotoxicity induced by IUdR-loaded PCL-PEG-coated magnetic NPs on a U87MG glioblastoma cell line [127]. It was found that these NPs have more toxicity against glioblastoma cells compared to IUdR alone. Irani et al. investigated the efficacy of CS/TMZ NPs-loaded PCL-PU nanofibers against U-87 MG human glioblastoma cells [128]. These nanofibers released TMZ for 30 days and significantly decreased the cell viability and survival of glioblastoma cells. Küçüktürkmen et al. examined the effects of pemetrexed- and miR-21 antisense oligonucleotide-loaded lipid-polymer hybrid NPs on glioblastoma cells [129]. These NPs gradually released pemetrexed over $10 \mathrm{~h}$ and the encapsulation of pemetrexed in lipid NPs increased the cellular uptake from $6 \%$ to $78 \%$. Also, confocal microscopy demonstrated that anti-miR-21 enhances the accumulation of lipid NPs in the nucleus of U87MG cells. Finally, it was shown that higher cytotoxicity was achieved by the delivery of anti-miR-21 and pemetrexed through a lipid-polymer hybrid NPs. Ahmad et al. investigated the beneficial effects of eugenol-encapsulated-CS-coated-PCL NPs for the treatment of cerebral ischemia [130]. It was shown that IN administration of these NPs increases their bioavailability in the rat brain and these NPs may lead to the treatment of cerebral ischemia. Irani et al. investigated the prolonged delivery of TMZ from electrospun PCL-Diol-b-PU/gold nanocomposite nanofibers for the treatment of glioblastoma tumors [131]. Their results demonstrated the decreased viability and survival of glioblastoma cells treated with these NPs. Varan and Bilensoy synthesized cationic PEGylated polycaprolactone NPs containing post-operation docetaxel for glioma treatment [132]. Their results revealed the higher cytotoxicity of these NPs compared to docetaxel alone.

\subsubsection{PACA}

Couvreur and co-workers were among the first to study PACA NPs in the treatment of brain diseases [204]. PACA NPs have improved some properties of drugs from the clinical point of view. Its NPs decrease the drug dosage and reduce the side effects of the drug. Also, PACA NPs improve drug bioavailability and half-life, and have a noninvasive route of administration. The most promising advantage of PACA NPs is the ability to overcome multidrug resistance (MDR) $[205,206]$. Cancerous cells possessing MDR are able to evade chemotherapeutic agents. Overexpressed p-glycoprotein is the main reason for MDR resistance in tumor cells [207-209]. Many drugs have been used for the treatment of brain diseases based on polysorbate 80-coated PACA NPs such as DOX, methotrexate, loperamide, tubocurarine, dalargin, kyotorphin, and the NMDA receptor antagonist MRZ 2/576 [210-215]. Wilson et al. [133] used PBCA NPs to deliver the anti-Alzheimer's drug tacrine. The results showed an increase in drug concentration in the liver and the spleen. The authors modified the surface of NPs with P80 and observed the penetration of drug-loaded NPs through the BBB. In the same study, the authors used rivastigmine, a reverse cholinesterase inhibitor. They encapsulated the drug in P80-coated PBCA NPs. They observed a 4-fold increase in drug concentration in the brain, in comparison with the control [79]. Ambruosi et al. [216] studied the effect of DOX-loaded PBCA NPs coated with different kinds of surfactants (P80, P188, and poloxamine 908) on glioblastoma in a rat model. The results showed a decrease in RES uptake and an increase in the antitumoral effect of DOX-loaded PBCA NPs coated with PS80 after IV injection [217]. 
Petri et al. [134] investigated the possible mechanisms for the delivery of DOX-loaded PBCA NPs that were coated with different surfactants (P188 and P80). DOX-PBCA NPs coated with P188, like DOX-PBCA NPs coated with P80, considerably increased the median survival rates and antitumor effect of DOX against an intracranial glioblastoma in rats. The authors found that ApoA-I adsorb considerably on the surface of NPs. The results showed that DOX-loaded PBCA NPs stabilized by P188 also produced considerable antitumor effects. Endocytosis through the endothelial cells of the brain capillary is the main strategy NPs use to cross the BBB [138]. Some of the plasma proteins adsorb, especially on the surface of P80-coated PBCA NPs, and trigger the receptor-mediated endocytosis of NPs and finally their penetration into the brain [218]. Yamamoto et al. [219] used PBCA NPs for the entrapment of TMZ. TMZ is a DNA-methylating agent applied for the treatment of melanoma and brain tumors. PBCA NPs showed controlled release of TMZ. The authors suggested that TMZ-PBCA NPs can be used for TMZ delivery to the brain without any effect on drug hydrolysis. Wang et al. [220] prepared P80-coated gemcitabine-PBCA NPs (GCTB-PBCA-NPs). GCTB is a pyrimidine nucleoside analog anticancer agent that has shown promising antitumor activity. $\mathrm{C} 6$ glioma cells treated with these NPs demonstrated the most dramatic changes in growth status and cell morphology. GCTB-PBCA NPs inhibited cell growth by arresting G0/G1 to $S$ phase transition, and cell proliferation slowed down significantly. Also, dramatic changes in cell morphology were observed, including nuclear vacuoles, ruptured cells, and dead cells and cell debris in the medium. Mulik et al. [135] used Apo E3-PBCA NPs as a curcumin delivery system to inhibit A $\beta$ and related oxidative stress in AD. Apo E3-PBCA NPs increased curcumin stability and sustained release. The results showed that the anti-apoptotic activity of Apo E3- curcumin-PBCA was increased 2-3-fold in comparison with curcumin-PBCA NPs. The authors suggested that ApoE3-curcumin-PBCA NPs can significantly increase the uptake of a drug across the BBB. Kurakhmaeva et al. [136] studied the antiparkinsonian effect of NGF-PBCA NPs coated with P80 in a mouse model for PD. The results showed improvement of the symptoms of oligokinesia after the administration of P80-(NGF)-PBCA NPs. Kreuter et al. [137] investigated the effect of different surfactants (poloxamer 184, 188, 388, 407 and poloxamine 908; polysorbate 20, 40, $60,80)$ on dalargin delivery across the BBB by PBCA NPs. The results showed that after IV injection of surfactant-dalargin-PBCA NPs to mice, only the surfactants polysorbate 20, 40, 60, and 80 were able to induce the passage of dalargin across the BBB. The authors showed that P80 enabled the highest induction of analgesia at both dosages of dalargin, $7.5 \mathrm{mg} / \mathrm{kg}$ as well as $10 \mathrm{mg} / \mathrm{kg}$. Kreuter et al. [138] confirmed that P80-PBCA NPs can deliver significant amounts of dalargin to the CNS. PEGylation of PACA NPs is another technology that can be used in drug delivery to the brain [15,77,178,221-225]. These PEGylated NPs are able to cross the BBB and penetrate the brain. It has been shown, however, that PACA NPs have limitations in clinical applications. The by-products that result from PBCA degradation can stimulate or damage the CNS [226]. In addition, it has been demonstrated that this kind of nanocarrier is not a good candidate for the treatment of chronic diseases because of the short duration of the pharmacological effect $[80,227]$.

\subsection{Natural Polymers}

\subsubsection{HSA}

HSA is a water-soluble and low-molecular-weight ( $\sim 66 \mathrm{kDa})$ protein. Some of the major roles of this abundant protein in the body include: enhancing the solubility of long-chain fatty acids, the transportation of different ions and compounds such as drugs and hormones, and the regulation of osmotic pressure in the blood circulation system [228]. These desirable characteristics, in addition to the long half-life of approximately 20 days in the circulation system, make it a potential candidate for drug delivery. NPs made of HSA have been investigated and fabricated for drug delivery to the brain and their applications in diagnostics and therapeutics [229,230]. Ulbrich et al. [92] investigated a stable nanoparticulate system to transport loperamide across the BBB. The authors used HSA NPs with covalently bound Tf or TfR mAbs (OX26 or R 17217). The results of the tail-flick test demonstrated 
that targeted HSA NPs were able to deliver loperamide across the BBB and induce antinociceptive (analgesic) effects in the brain. In another study, the same authors used HSA NPs with covalently attached insulin or an anti-insulin receptor monoclonal antibody to deliver loperamide across the BBB. The results showed that NPs induced significant antinociceptive effects in the tail-flick test [144]. Dadparvar et al. [231] investigated the binding of HI 6 dimethanesulfonate and HI 6 dichloride monohydrate to HSA NPs for the treatment of poisoning by organophosphorus compounds. In vitro assessment of the drug activity showed that HSA NPs transport drugs through the blood-brain barrier. Zensi et al. [229] prepared HSA NPs targeted with covalently bound Apo E by a desolvation technique. The authors intravenously injected Apo E-HSA NPs into the SV 129 mice. Apo E-HSA NPs were detected in the brain and neurons of SV 129 mice after 15 and $30 \mathrm{~min}$. They suggested that drug-loaded NPs' entrance into the brain requires an interaction between Apo E and the LDL receptor family and receptor-mediated endocytosis. Similar results were observed in other studies [232,233]. Ruan et al. synthesized substance P-modified HSA NPs containing paclitaxel for targeting gliomas [145]. These NPs had great properties in terms of drug-loading content (7.89\%), entrapment efficiency $(85.7 \%)$, spherical structure with a size of $150 \mathrm{~nm}$, and zeta potential of $-12.0 \mathrm{mV}$. These NPs showed great uptake by brain capillary endothelial cells and U87 cells; in addition, it was found that they were toxic for glioma cells, so they can be considered as novel agents for targeting gliomas. Wong and Ho investigated the efficiency of serum albumin as a nanoparticulate carrier for the delivery of R-flurbiprofen and the treatment of AD [146]. Their results showed that the IN route to administration of these NPs is preferred to oral and IN administration of a simple R-flurbiprofen solution so that a higher brain to-plasma ratio profile was achieved by this administration and it was demonstrated that these NPs are potential therapeutic agents for the amelioration of mitochondrial dysfunction in AD. Liang et al. prepared carriers by conjugation of borneol, muscone, and menthol to BSA for targeting gliomas (Figure 4) [147]. BSA was found to improve the drug accumulation in the glioma region after penetration of the blood-brain barrier (BBB) (Figure 5).

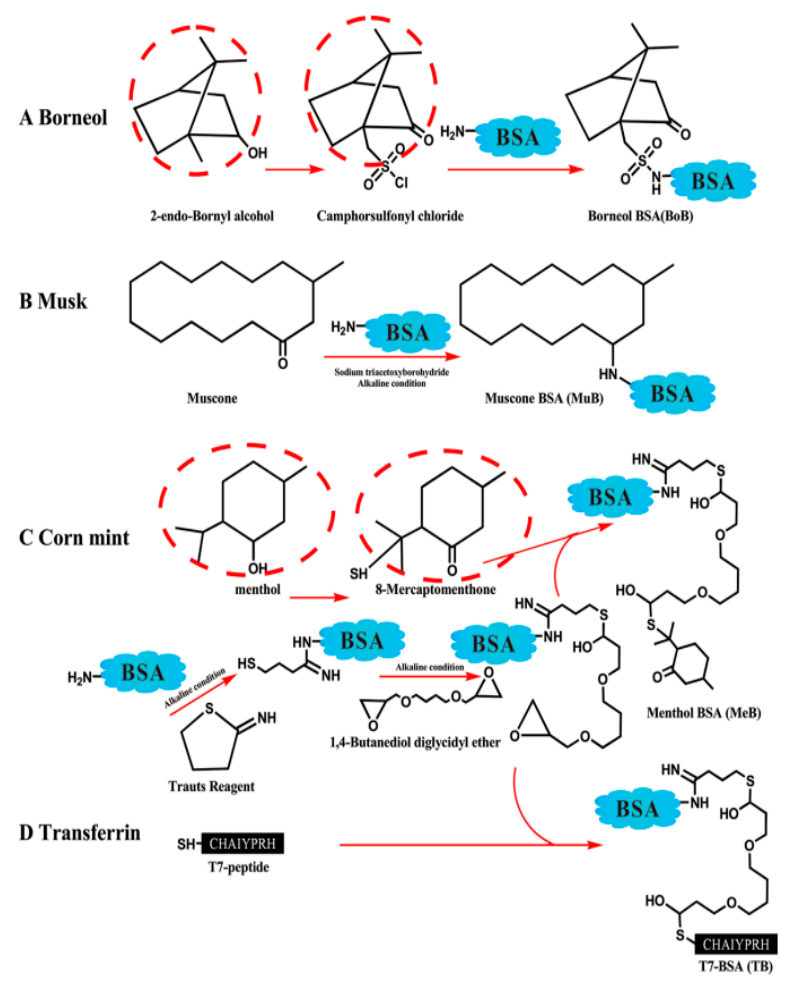

Figure 4. Schemes of modified albumin including borneol BSA (A), muscone BSA (B), menthol BSA (C), and T7 BSA (D). Reproduced with permission from Liang, J.; Gao, C.; Zhu, Y.; Ling, C.; Wang, Q.; Huang, Y.; Qin, J.; Wang, J.; Lu, W.; Wang, J. Natural Brain Penetration Enhancer-Modified Albumin Nanoparticles for Glioma Targeting Delivery. ACS Appl. Mater. Interfaces 2018 [147]. 


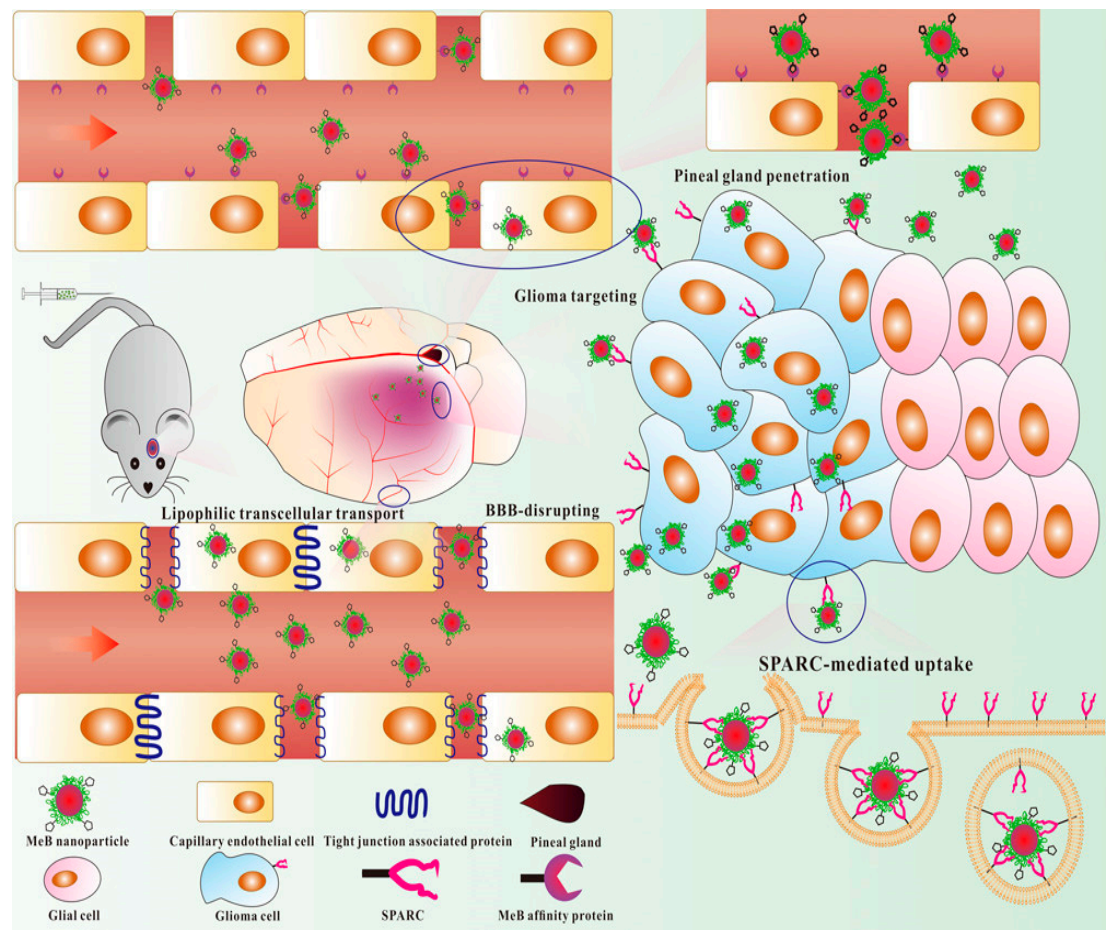

Figure 5. Schematic diagram of possible BBB penetration pathways and glioma-targeting ability of BPE-BSA-based NPs. Reproduced with permission from Liang, J.; Gao, C.; Zhu, Y.; Ling, C.; Wang, Q.; Huang, Y.; Qin, J.; Wang, J.; Lu, W.; Wang, J. Natural Brain Penetration Enhancer-Modified Albumin Nanoparticles for Glioma Targeting Delivery. ACS Appl. Mater. Interfaces 2018 [147].

These carriers had great biocompatibility; it was found that they efficiently penetrate the BBB and are captured by cells, showing their efficiency for drug delivery in gliomas.

\subsubsection{Gelatin (GE)}

Gelatin (GE) is a by-product of denatured and partially hydrolyzed collagen, which is extensively used in tissue engineering and therapeutic delivery $[234,235]$. Also, GE has bioactive materials such as arginine-glycine-aspartic acid, which gives GE a cell attachment property and makes GE valuable as a biomaterial [28,236-241]. At present, GE and its blends are used in the food industry and in medical products [242,243]. The nontoxic, biodegradable, and bioactive properties of GE make it a suitable carrier for drug delivery [244]. Kaur et al. [148] encapsulated an anti-HIV drug (hydrophilic didanosine) in GE NPs coated with mannan. Free didanosine drug is not able to penetrate the BBB. However, the brain concentration of the drug increased after the administration of GE NPs. GE-siloxane NPs improved the delivery of a model drug (rhodamine B isothiocyanate) to the brain. A cell-penetrating peptide (SynB) was conjugated to the NPs. The nanocomplexes were efficiently taken up by brain capillary endothelial cells and showed proper biocompatibility and nontoxicity [149]. Nejat et al. synthesized cardamom extract-loaded GE NPs for the treatment of glioblastomas [150]. These NPs had a diameter in the range of $40-200 \mathrm{~nm}$, a zeta potential of $-40.1 \mathrm{mV}$, and entrapment efficiency of $70 \%$, and it was found that these NPs have cytotoxic effects on human glioblastoma cancer U87MG cells.

\subsubsection{Chitosan (CS)}

CS is a water-soluble cationic polysaccharide with a positive charge and biocompatible and biodegradable characteristics $[245,246]$. The nonallergenic and nontoxic characteristics of CS make it an appropriate choice for delivery systems in pharmaceutical applications [247-249]. CS has the ability to make epithelial cells permeable by means of its interaction with the tight junction and then opening them to cross the epithelial barrier [250]. The absorption and penetration of different kinds of drugs 
(e.g., proteins, peptides, hormones, etc.) have been studied through the nasal epithelium [251-253]. IN administration of interferon $\beta-1 b$ (IFN $\beta-1 b)$ was investigated by Ross et al. [254] in multiple sclerosis. The aim was the targeted delivery of IFN $\beta-1 b$ to the rat CNS. Autoradiography studies showed the active and efficient delivery of IFN $\beta-1 b$ to the CNS by IN administration. Delivery of IFN $\beta-1 b$ to the monkey CNS has been studied by Thorne et al. [255]. This work was the first investigation to determine CNS drug distribution in nonhuman primates. Studies showed that IN administration of IFN $\beta-1 b$ resulted in inefficient targeting of the CNS. The authors concluded that IN administration of drugs is a noninvasive method to access the brain and direct drugs to the CNS. Moreover, new technology-based delivery systems have been used for drug delivery to the brain through the nose to brain pathway or IN administration. Wang et al. [151] fabricated estradiol-loaded CS NPs by the ionic gelation method. The authors compared the uptake of the drug into the cerebrospinal fluid (CSF) between the two methods of administration (IN and IV). The results confirmed the efficient delivery of estradiol to the CSF by CS NPs through the IN route of administration. Aktas et al. [152] investigated the brain delivery of anticaspase peptide Z-DEVD-FMK by CS-poly(ethylene glycol) (PEG). They used the avidin-biotin system to attach the OX26 monoclonal antibody to the surface of NPs. The results showed that, after the intravascular administration of CS-PEG-biotin-avidin/OX26, NPs can lead to the delivery of anticaspase peptide Z-DEVD-FMK to the brain, outside of the intravascular compartment. Trapani et al. [154] prepared and characterized dopamine-loaded CS NPs. In vivo results showed enhanced brain delivery of dopamine by these nanocarriers. Moreover, CS NPs have shown their potential in the development of a delivery system to overcome the BBB problem [256]. Tammam et al. synthesized CS NPs for nuclear and cytoplasmic delivery of lactoferrin in gliomas [155]. Interestingly, it was found that the cytotoxicity of NPs containing lactoferrin on gliomas is due to their cytoplasmic allocation. Gu et al. prepared antibody-modified CS NPs to deliver siRNA for targeting HIV replication in astrocytes [156]. It was demonstrated that the antibody moiety increases the knockdown effect of siRNA-loaded NPs, showing their efficiency in inhibiting HIV replication in astrocytes. Gholami et al. investigated the proficiency of super-paramagnetic iron oxide/DOX-loaded CS NPs for glioblastoma theranostics [157]. Magnetic resonance imaging (MRI) demonstrated the high uptake of NPs by C6 glioma cells, showing their application in the diagnosis of glioblastoma. Xu et al. investigated the effect of lactoferrin-coated polysaccharide NPs based on CS hydrochloride/hyaluronic acid/PEG on brain gliomas [158]. These NPs were remarkably captured by brain capillary endothelial cells and can penetrate the BBB. Also, 1, 3ß-glucan-anchored paclitaxel-loaded CS cross-linked targeted NPs have been proposed as potential therapeutic options for the treatment of brain tumors $[159,160]$.

\section{Conclusions}

Although the BBB acts as vital protection for the brain against foreign substances, its structure is a major obstacle to the delivery of drugs into the brain for the treatment of CNS diseases. Most of the drugs that are presently being used for brain diseases use the IV route of administration and thereby face the reticuloendothelial system (RES), which removes them from the bloodstream. Also, it has been shown that this route of drug administration is related to systemic distribution and side effects and reduces the drug efficacy and bioavailability. Progress in nanotechnology-based drug delivery systems has overcome some but not all of these problems. Conditional and targeted polymeric NPs that are sensitive to the specific situation or environment for controlled and sustainable drug release, in combination with the IN route of administration, are the newest technology for drug delivery into the brain. This targeted delivery via IN administration solves the major problems involving the BBB, increases drug efficacy, and decreases drug side effects.

Author Contributions: Conceptualization: S.S.; writing-original draft preparation: S.S., M.A., A.Z., R.R., and E.G.A.; writing-review and editing: A.P., R.M., A.K., and V.K.T. All authors have read and agreed to the published version of the manuscript.

Funding: This research received no external funding 
Acknowledgments: The authors are thankful to the Laboratory of Bioactive Polymeric Materials for Biomedical and Environmental Applications (BioLab). Also, financial support from the National Elite Foundation (NEF) is gratefully acknowledged.

Conflicts of Interest: The authors declare no conflict of interest.

\section{Abbreviations}

\begin{tabular}{|c|c|}
\hline $\mathrm{AD}$ & Alzheimer's disease \\
\hline PD & Parkinson's disease \\
\hline PLA & Polylactic acid \\
\hline PGA & Polyglycolic acid \\
\hline PLGA & Poly D,L-lactide-co-glycolide \\
\hline PVA & Polyvinyl alcohol \\
\hline PCL & Poly ( $\varepsilon$-caprolactone) \\
\hline PNPCL & Poly ( $N$-isopropylacrylamide)-b-poly(3-caprolactone) \\
\hline PACA & Poly (alkyl cyanoacrylate) \\
\hline PBCA & Poly (butyl cyanoacrylate) \\
\hline PEG & Polyethylene glycol \\
\hline P80 & Polysorbate 80 \\
\hline P188 & Poloxamer 188 \\
\hline HSA & Human serum albumin \\
\hline CS & Chitosan \\
\hline $\mathrm{CPP}$ & Cell-penetrating peptides \\
\hline BBB & Blood-brain barrier \\
\hline CNS & Central nervous system \\
\hline GE & Gelatin \\
\hline NDDs & Neurodegenerative diseases \\
\hline MS & Multiple sclerosis \\
\hline NPs & Nanoparticles \\
\hline RES & Reticuloendothelial system \\
\hline ROS & Reactive oxygen species \\
\hline SOD & Superoxide dismutase \\
\hline CSF & Cerebrospinal fluid \\
\hline IV & Intravenous \\
\hline IN & Intranasal \\
\hline MDR & Multidrug resistance \\
\hline NT-1 & Neurotoxin-I \\
\hline TRH & Thyrotropin-releasing hormone \\
\hline Lf & Lactoferrin \\
\hline LDLR & Low-density lipoprotein receptor \\
\hline DOX & Doxorubicin \\
\hline$A \beta$ & Amyloid beta \\
\hline GABA & Gamma-aminobutyric acid \\
\hline TMZ & Temozolomide \\
\hline Tf & Transferrin \\
\hline TMC & Trimethylated chitosan (TMC) \\
\hline GCTB & Gemcitabine \\
\hline NGF & Nerve growth factor \\
\hline Apo & Apolipoprotein \\
\hline $\operatorname{IFN} \beta-1 b$ & Interferon $\beta-1 b$ \\
\hline
\end{tabular}




\section{References}

1. Barnabas, W. Drug targeting strategies into the brain for treating neurological diseases. J. Neurosci. Methods 2019, 311, 133-146. [CrossRef]

2. Yan, S.; Tu, Z.; Li, S.; Li, X.J. Use of CRISPR/Cas9 to model brain diseases. Prog. Neuro Psychopharmacol. Biol. Psychiatry 2018, 81, 488-492. [CrossRef] [PubMed]

3. Sweeney, M.D.; Sagare, A.P.; Zlokovic, B.V. Blood-brain barrier breakdown in Alzheimer disease and other neurodegenerative disorders. Nat. Rev. Neurol. 2018, 14, 133. [CrossRef] [PubMed]

4. Gould, J. Breaking down the epidemiology of brain cancer. Nature 2018, 561, S40-S41. [CrossRef] [PubMed]

5. Jemal, A.; Siegel, R.; Ward, E.; Murray, T.; Xu, J.; Thun, M.J. Cancer Statistics. CA Cancer J. Clin. 2007, 57, 43-66. [CrossRef]

6. Sonali, M.K.V.; Singh, R.P.; Agrawal, P.; Mehata, A.K.; Datta Maroti Pawde, N.; Sonkar, R.; Muthu, M.S. Nanotheranostics: Emerging strategies for early diagnosis and therapy of brain cancer. Nanotheranostics 2018, 2, 70. [CrossRef]

7. Tang, W.; Fan, W.; Lau, J.; Deng, L.; Shen, Z.; Chen, X. Emerging blood-brain-barrier-crossing nanotechnology for brain cancer theranostics. Chem. Soc. Rev. 2019. [CrossRef]

8. Lucienne, J.J. The targeted delivery of cancer drugs across the blood-brain barrier: Chemical modifications of drugs or drug-nanoparticles? Drug Discov. Today 2008, 13, 1099-1106.

9. Phillips, K.A.; Fadul, C.E.; Schiff, D. Neurologic and Medical Management of Brain Tumors. Neurol. Clin. 2018, 36, 449-466. [CrossRef]

10. Abiwinanda, N.; Hanif, M.; Hesaputra, S.T.; Handayani, A.; Mengko, T.R. Brain tumor classification using convolutional neural network. In World Congress on Medical Physics and Biomedical Engineering 2018; Springer: Prague, Czech Republic, 2018; pp. 183-189.

11. Jagat, R.K.; Ganesh, M.; Rupinder, K.K. Recent advances in nanoneurology for drug delivery to the brain. Curr. Nanosci. 2009, 5, 441-448.

12. Association, A.s. 2018 Alzheimer's disease facts and figures. Alzheimer's Dement. 2018, 14, 367-429.

13. Scorza, F.A.; Fiorini, A.C.; Scorza, C.A.; Finsterer, J. Cardiac abnormalities in Parkinson's disease and Parkinsonism. J. Clin. Neurosci. 2018, 53, 1-5. [CrossRef] [PubMed]

14. Tee, B.L.; Ibarrola, E.M.L.; Geschwind, M.D. Prion Diseases. Neurol. Clin. 2018, 36, 865-897. [CrossRef] [PubMed]

15. Denora, N.; Trapani, A.; Laquintana, V.; Lopedota, A.; Trapani, G. Recent advances in medicinal chemistry and pharmaceutical technology-Strategies for drug delivery to the brain. Curr. Top. Med. Chem. 2009, 9, 182-196. [CrossRef]

16. Mayeux, R. Epidemiology of neurodegeneration. Annu. Rev. Neurosci. 2003, 26, 81-104. [CrossRef]

17. Erkkinen, M.G.; Kim, M.O.; Geschwind, M.D. Clinical neurology and epidemiology of the major neurodegenerative diseases. Cold Spring Harb. Perspect. Biol. 2018, 10, a033118. [CrossRef]

18. Jain, K.K. Drug Delivery in Central Nervous System Disorders: Technologies, Companies and Markets. Jain PharmaBiotech. 2019. Available online: http://pharmabiotech.ch/reports/cns/contents.pdf (accessed on 10 January 2020).

19. Ivona, B.; Harry, W.M.S.; Christoph, S.; Pilar, M.M. Delivery of peptide and protein drugs over the blood-brain barrier. Prog. Neurobiol. 2009, 87, 212-251.

20. Pathan, S.A.; Iqbal, Z.; Zaidi, S.M.; Talegaonkar, S.; Vohra, D.; Jain, G.K.; Azeem, A.; Jain, N.; Lalani, J.R.; Khar, R.K.; et al. CNS drug delivery systems: Novel approaches. Recent Pat. Drug Deliv. Formul. 2009, 3, 71-89. [CrossRef]

21. Pardridge, W.M. Why is the global CNS pharmaceutical market so under-penetrated? Drug Discov. Today 2002, 7, 5-7. [CrossRef]

22. Neurodegenerative Diseases Drugs Market: Global Market Analysis, Insights and Forecast, 2019-2026; Fortune Business Insights: Maharashtra, India, 2019.

23. Brook, E.; Mamo, J.; Wong, R.; Al-Salami, H.; Falasca, M.; Lam, V.; Takechi, R. Blood-brain barrier disturbances in diabetes-associated dementia: Therapeutic potential for cannabinoids. Pharmacol. Res. 2019, 141, $291-297$. [CrossRef]

24. Dwivedi, N.; Shah, J.; Mishra, V.; Tambuwala, M.; Kesharwani, P. Nanoneuromedicine for management of neurodegenerative disorder. J. Drug Deliv. Sci. Technol. 2018, 49, 477-490. [CrossRef] 
25. Pollak, T.A.; Drndarski, S.; Stone, J.M.; David, A.S.; McGuire, P.; Abbott, N.J. The blood-brain barrier in psychosis. Lancet Psychiatry 2018, 5, 79-92. [CrossRef]

26. You, L.; Wang, J.; Liu, T.; Zhang, Y.; Han, X.; Wang, T.; Guo, S.; Dong, T.; Xu, J.; Anderson, G.J. Targeted Brain Delivery of Rabies Virus Glycoprotein 29-Modified Deferoxamine-Loaded Nanoparticles Reverses Functional Deficits in Parkinsonian Mice. ACS Nano 2018, 12, 4123-4139. [CrossRef] [PubMed]

27. Goasdoué, K.; Miller, S.M.; Colditz, P.B.; Björkman, S.T. The blood-brain barrier; protecting the developing fetal brain. Placenta 2017, 54, 111-116. [CrossRef] [PubMed]

28. Murphy, C.A.; Costa, J.B.; Silva-Correia, J.; Oliveira, J.M.; Reis, R.L.; Collins, M.N. Biopolymers and polymers in the search of alternative treatments for meniscal regeneration: State of the art and future trends. Appl. Mater. Today 2018, 12, 51-71. [CrossRef]

29. Verheggen, I.; Van Boxtel, M.; Verhey, F.; Jansen, J.; Backes, W. Interaction between blood-brain barrier and glymphatic system in solute clearance. Neurosci. Biobehav. Rev. 2018, 90, 26-33. [CrossRef]

30. Ehrlich, P. Das Sauerstoff-Bedurfnis des Organismus: Eine Farbenanalytische Studie; Hirschwald: Berlin, Germany, 1885.

31. Myrtill, S.; Ulrich, F.; André, G.; Michael, N. Can nanoparticles end up in the brain? NanoTrust Doss. 2010, 14, $1-4$.

32. Bickel, U.; Yoshikawa, T.; Pardridge, W.M. Delivery of peptides and proteins through the blood-brain barrier. Adv. Drug Deliv. Rev. 2001, 46, 247-279. [CrossRef]

33. Serlin, Y.; Shelef, I.; Knyazer, B.; Friedman, A. Anatomy and physiology of the blood-brain barrier. Semin. Cell Dev. Biol. 2015, 38, 2-6. [CrossRef]

34. Pardridge, W.M. Molecular biology of the blood-brain barrier. Mol. Biotechnol. 2005, 30, 57-70. [CrossRef]

35. Daneman, R.; Prat, A. The blood-brain barrier. Cold Spring Harb. Perspect. Biol. 2015, 7, a020412. [CrossRef] [PubMed]

36. Sweeney, M.D.; Zhao, Z.; Montagne, A.; Nelson, A.R.; Zlokovic, B.V. Blood-brain barrier: From physiology to disease and back. Physiol. Rev. 2018, 99, 21-78. [CrossRef] [PubMed]

37. Abbott, N.J.; Patabendige, A.A.; Dolman, D.E.; Yusof, S.R.; Begley, D.J. Structure and function of the blood-brain barrier. Neurobiol. Dis. 2010, 37, 13-25. [CrossRef] [PubMed]

38. Furtado, D.; Björnmalm, M.; Ayton, S.; Bush, A.I.; Kempe, K.; Caruso, F. Overcoming the blood-brain barrier: The role of nanomaterials in treating neurological diseases. Adv. Mater. 2018, 30, 1801362. [CrossRef] [PubMed]

39. Khaitan, D.; Reddy, P.L.; Ningaraj, N. Targeting brain tumors with nanomedicines: Overcoming blood brain barrier challenges. Curr. Clin. Pharmacol. 2018, 13, 110-119. [CrossRef] [PubMed]

40. Teleanu, D.M.; Chircov, C.; Grumezescu, A.M.; Volceanov, A.; Teleanu, R.I. Blood-brain delivery methods using nanotechnology. Pharmaceutics 2018, 10, 269. [CrossRef] [PubMed]

41. Li, G.; Shao, K.; Umeshappa, C.S. Recent progress in blood-brain barrier transportation research. In Brain Targeted Drug Delivery System; Elsevier: Amsterdam, The Netherlands, 2019; pp. 33-51.

42. Sharma, G.; Sharma, A.R.; Lee, S.S.; Bhattacharya, M.; Nam, J.S.; Chakraborty, C. Advances in nanocarriers enabled brain targeted drug delivery across blood brain barrier. Int. J. Pharm. 2019, 559, 360-372. [CrossRef] [PubMed]

43. Kim, J.; Shamul, J.G.; Shah, S.R.; Shin, A.; Lee, B.J.; Quinones-Hinojosa, A.; Green, J.J. Verteporfin-loaded poly (ethylene glycol)-poly (beta-amino ester)-poly (ethylene glycol) triblock micelles for cancer therapy. Biomacromolecules 2018, 19, 3361-3370. [CrossRef]

44. Ahmadi, Z.; Mohammadinejad, R.; Ashrafizadeh, M. Technology. Drug delivery systems for resveratrol, a non-flavonoid polyphenol: Emerging evidence in last decades. J. Drug Deliv. Sci. Technol. 2019, 51, 591-604. [CrossRef]

45. Shah, S.R.; Kim, J.; Schiapparelli, P.; Vazquez-Ramos, C.A.; Martinez Gutierrez, J.C.; Ruiz-Valls, A.; Inman, K.; Shamul, J.G.; Green, J.J.; Quinones-Hinojosa, A. Verteporfin-loaded polymeric microparticles for intratumoral treatment of brain cancer. Mol. Pharm. 2019, 16, 1433-1443. [CrossRef]

46. Erdő, F.; Bors, L.A.; Farkas, D.; Bajza, A.; Gizurarson, S. Evaluation of intranasal delivery route of drug administration for brain targeting. Brain Res. Bull. 2018, 143, 155-170. [CrossRef] [PubMed]

47. Rosas-Hernandez, H.; Cuevas, E.; Lantz, S.M.; Imam, S.Z.; Paule, M.G.; Ali, S.F. Blood-brain barrier: Physiological and functional considerations. In Handbook of Developmental Neurotoxicology; Elsevier: Amsterdam, The Netherlands, 2018; pp. 229-236. 
48. Pardridge, W.M. The blood-brain barrier: Bottleneck in brain drug development. NeuroRx 2005, 2, 3-14. [CrossRef] [PubMed]

49. Jeffrey, P.; Summerfield, S. Assessment of the blood-brain barrier in CNS drug discovery. Neurobiol. Discov. 2010, 37, 33-37. [CrossRef] [PubMed]

50. Sharif, Y.; Jumah, F.; Coplan, L.; Krosser, A.; Sharif, K.; Tubbs, R.S. Blood brain barrier: A review of its anatomy and physiology in health and disease. Clin. Anat. 2018, 31, 812-823. [CrossRef]

51. Moura, R.P.; Martins, C.; Pinto, S.; Sousa, F.; Sarmento, B. Blood-brain barrier receptors and transporters: An insight on their function and how to exploit them through nanotechnology. Expert Opin. Drug Deliv. 2019, 16, 271-285. [CrossRef]

52. Kumar, M.; Sharma, P.; Maheshwari, R.; Tekade, M.; Shrivastava, S.K.; Tekade, R.K. Beyond the Blood-Brain Barrier: Facing New Challenges and Prospects of Nanotechnology-Mediated Targeted Delivery to the Brain. In Nanotechnology-Based Targeted Drug Delivery Systems for Brain Tumors; Elsevier: Amsterdam, The Netherlands, 2018; pp. 397-437.

53. Vieira, D.B.; Gamarra, L.F. Multifunctional Nanoparticles for Successful Targeted Drug Delivery across the Blood-Brain Barrier. In Molecular Insight of Drug Design; IntechOpen: London, UK, 2018.

54. Poovaiah, N.; Davoudi, Z.; Peng, H.; Schlichtmann, B.; Mallapragada, S.; Narasimhan, B.; Wang, Q. Treatment of neurodegenerative disorders through the blood-brain barrier using nanocarriers. Nanoscale 2018, 10, 16962-16983. [CrossRef]

55. Wu, Z. Nanoparticles: Improving the efficiency of drug administration across the blood-brain barrier. J. Drug Deliv. Ther. 2019, 9, 496-499.

56. Tosi, G.; Costantino, L.; Ruozi, B.; Forni, F.; Vandelli, M.A. Polymeric nanoparticles for the drug delivery to the central nervous system. Expert Opin. Drug Deliv. 2008, 5, 155-174. [CrossRef]

57. Sharma, G.; Bouton, C. Administration of a Drug through the Blood Brain Barrier Using Stimuli-Responsive Nanoparticles. U.S. Patent 10285934, 14 May 2019.

58. He, Q.; Liu, J.; Liang, J.; Liu, X.; Li, W.; Liu, Z.; Ding, Z.; Tuo, D. Towards improvements for penetrating the blood-brain barrier-Recent progress from a material and pharmaceutical perspective. Cells 2018, 7, 24. [CrossRef]

59. Lei, C.; Davoodi, P.; Zhan, W.; Chow, P.K.H.; Wang, C.H. Development of Nanoparticles for Drug Delivery to Brain Tumor: The Effect of Surface Materials on Penetration into Brain Tissue. J. Pharm. Sci. 2019, 108, 1736-1745. [CrossRef]

60. Ceña, V.; Játiva, P. Nanoparticle Crossing of Blood-Brain Barrier: A Road to New Therapeutic Approaches to Central Nervous System Diseases. Nanomedicine 2018. [CrossRef] [PubMed]

61. Khalil, N.M.; Mainardes, R.M. Colloidal polymeric nanoparticles and brain drug delivery. Curr. Drug Deliv. 2009, 6, 261-273. [CrossRef]

62. Zhou, Y.; Peng, Z.; Seven, E.S.; Leblanc, R.M. Crossing the blood-brain barrier with nanoparticles. J. Control. Release 2018, 270, 290-303. [CrossRef]

63. Khongkow, M.; Yata, T.; Boonrungsiman, S.; Ruktanonchai, U.R.; Graham, D.; Namdee, K. Surface modification of gold nanoparticles with neuron-targeted exosome for enhanced blood-brain barrier penetration. Sci. Rep. 2019, 9, 8278. [CrossRef] [PubMed]

64. Farokhzad, O.C.; Langer, R. Impact of nanotechnology on drug delivery. ACS Nano 2009, 3, 16-20. [CrossRef] [PubMed]

65. Errico, C.; Bartoli, C.; Chiellini, F.; Chiellini, E. Poly(hydroxyalkanoates)-based polymeric nanoparticles for drug delivery. J. Biomed. Biotechnol. 2009, 2009, 571702. [CrossRef] [PubMed]

66. Prokai, L. Peptide drug delivery into the central nervous system. Prog. Drug Res. 1998, 51, 95-131.

67. Zuzana, A.; Martina, M.; Vladimir, K.; Tomas, M. Therapeutic application of peptides and proteins: Parenteral forever? Trends Biotechnol. 2009, 27, 628-635.

68. Ajdary, M.; Moosavi, M.; Rahmati, M.; Falahati, M.; Mahboubi, M.; Mandegary, A.; Jangjoo, S.; Mohammadinejad, R.; Varma, R. Health concerns of various nanoparticles: A review of their in vitro and in vivo toxicity. Nanomaterials 2018, 8, 634. [CrossRef]

69. Nadimi, A.E.; Ebrahimipour, S.Y.; Afshar, E.G.; Falahati-Pour, S.K.; Ahmadi, Z.; Mohammadinejad, R.; Mohamadi, M. Nano-scale drug delivery systems for antiarrhythmic agents. Eur. J. Med. Chem. 2018, 157, 1153-1163. [CrossRef] 
70. Mohammadinejad, R.; Moosavi, M.A.; Tavakol, S.; Vardar, D.Ö.; Hosseini, A.; Rahmati, M.; Dini, L.; Hussain, S.; Mandegary, A.; Klionsky, D.J. Necrotic, apoptotic and autophagic cell fates triggered by nanoparticles. Autophagy 2019, 15, 4-33. [CrossRef] [PubMed]

71. Shin, S.W.; Song, I.H.; Um, S.H. Role of physicochemical properties in nanoparticle toxicity. Nanomaterials 2015, 5, 1351-1365. [CrossRef] [PubMed]

72. Fröhlich, E. The role of surface charge in cellular uptake and cytotoxicity of medical nanoparticles. Int. J. Nanomed. 2012, 7, 5577. [CrossRef] [PubMed]

73. Jo, D.H.; Kim, J.H.; Lee, T.G.; Kim, J.H. Size, surface charge, and shape determine therapeutic effects of nanoparticles on brain and retinal diseases. Nanomed. Nanotechnol. Biol. Med. 2015, 11, 1603-1611. [CrossRef] [PubMed]

74. Brigger, I.; Morizet, J.; Aubert, G.; Chacun, H.; Terrier-Lacombe, M.J.; Couvreur, P.; Vassal, G. Poly(ethylene glycol) coated hexadecylcyanoacrylate nanospheres display a combined effect for brain tumor targeting. J. Pharmacol. Exp. Ther. 2002, 303, 928-936. [CrossRef]

75. Chiellini, E.E.; Chiellini, F.; Solaro, R. Bioerodible polymeric nanoparticles for targeted delivery of proteic drugs. J. Nanosci. Nanotechnol. 2006, 6, 3040-3047. [CrossRef]

76. Kreuter, J.; Alyautdin, R.N.; Kharkevich, D.A.; Ivanov, A.A. Passage of peptides through the blood-brain barrier with colloidal polymer particles (nanoparticles). Brain Res. 1995, 674, 171-174. [CrossRef]

77. Andrieux, K.; Couvreur, P. Polyalkylcyanoacrylate nanoparticles for delivery of drugs across the blood-brain barrier. Wiley Interdiscip. Rev. Nanomed. Nanobiotechnol. 2009, 1, 463-474. [CrossRef]

78. Graf, A.; McDowell, A.; Rades, T. Poly(alkylcyanoacrylate) nanoparticles for enhanced delivery of therapeutics: Is there real potential? Expert Opin. Drug Deliv. 2009, 6, 371-387. [CrossRef]

79. Wilson, B.; Samanta, M.K.; Santhi, K.; Kumar, K.P.; Paramakrishnan, N.; Suresh, B. Poly(n-butylcyanoacrylate) nanoparticles coated with polysorbate 80 for the targeted delivery of rivastigmine into the brain to treat Alzheimer's disease. Brain Res. 2008, 1200, 159-168. [CrossRef]

80. Olivier, J.C. Drug transport to brain with targeted nanoparticles. NeuroRx 2005, 2, 108-119. [CrossRef] [PubMed]

81. Wu, J.; Wang, K.; Peng, Y. Advances in Synthesis and Application of Nanometer Drug Carriers. Charact. Appl. Nanomater. 2018, 1. [CrossRef]

82. Kim, J.; Ahn, S.I.; Kim, Y. Nanotherapeutics engineered to cross the blood-brain barrier for advanced drug delivery to the central nervous system. J. Ind. Eng. Chem. 2019, 73, 8-18. [CrossRef] [PubMed]

83. Sarin, H. Recent progress towards development of effective systemic chemotherapy for the treatment of malignant brain tumors. J. Transl. Med. 2009, 7, 77. [CrossRef]

84. Li, X.; Tsibouklis, J.; Weng, T.; Zhang, B.; Yin, G.; Feng, G.; Cui, Y.; Savina, I.N.; Mikhalovska, L.I.; Sandeman, S.R. Nano carriers for drug transport across the blood-brain barrier. J. Drug Target. 2017, 25, 17-28. [CrossRef]

85. Zeiadeh, I.; Najjar, A.; Karaman, R. Strategies for enhancing the permeation of CNS-active drugs through the blood-brain barrier: A review. Molecules 2018, 23, 1289. [CrossRef]

86. Muthu, M.S.; Singh, S. Targeted nanomedicines: Effective treatment modalities for cancer, AIDS and brain disorders. Nanomedicine 2009, 4, 105-118. [CrossRef]

87. Debbage, P. Targeted drugs and nanomedicine: Present and future. Curr. Pharm. Des. 2009, 15, $153-172$. [CrossRef]

88. Abdul Razzak, R.; Florence, G.J.; Gunn-Moore, F.J. Approaches to CNS drug delivery with a focus on transporter-mediated transcytosis. Int. J. Mol. Sci. 2019, 20, 3108. [CrossRef]

89. Bhatt, P.; Narvekar, P. Challenges and Strategies for Drug Transport across the Blood Brain Barrier. ARC J. Neurosci. 2018, 3, 17-21.

90. Kratzer, I.; Wernig, K.; Panzenboeck, U.; Bernhart, E.; Reicher, H.; Wronski, R.; Windisch, M.; Hammer, A.; Malle, E.; Zimmer, A.; et al. Apolipoprotein A-I coating of protamine-oligonucleotide nanoparticles increases particle uptake and transcytosis in an in vitro model of the blood-brain barrier. J. Control. Release 2007, 117, 301-311. [CrossRef] [PubMed]

91. Mishra, V.; Mahor, S.; Rawat, A.; Gupta, P.N.; Dubey, P.; Khatri, K.; Vyas, S.P. Targeted brain delivery of AZT via transferrin anchored pegylated albumin nanoparticles. J. Drug Target. 2006, 14, 45-53. [CrossRef] [PubMed] 
92. Ulbrich, K.; Hekmatara, T.; Herbert, E.; Kreuter, J. Transferrin- and transferrin-receptor-antibody-modified nanoparticles enable drug delivery across the blood-brain barrier (BBB). Eur. J. Pharm. Biopharm. 2009, 71, 251-256. [CrossRef] [PubMed]

93. Jain, A.; Jain, A.; Garg, N.K.; Tyagi, R.K.; Singh, B.; Katare, O.P.; Webster, T.J.; Soni, V. Surface engineered polymeric nanocarriers mediate the delivery of transferrin-methotrexate conjugates for an improved understanding of brain cancer. Acta Biomater. 2015, 24, 140-151. [CrossRef] [PubMed]

94. Gagliardi, M.; Borri, C. Polymer nanoparticles as smart carriers for the enhanced release of therapeutic agents to the CNS. Curr. Pharm. Des. 2017, 23, 393-410. [CrossRef] [PubMed]

95. Kasinathan, N.; Jagani, H.V.; Alex, A.T.; Volety, S.M.; Rao, J.V. Strategies for drug delivery to the central nervous system by systemic route. Drug Deliv. 2015, 22, 243-257. [CrossRef] [PubMed]

96. Song, Q.; Song, H.; Xu, J.; Huang, J.; Hu, M.; Gu, X.; Chen, J.; Zheng, G.; Chen, H.; Gao, X. Biomimetic ApoE-Reconstituted High Density Lipoprotein Nanocarrier for Blood-Brain Barrier Penetration and Amyloid Beta-Targeting Drug Delivery. Mol. Pharm. 2016, 13, 3976-3987. [CrossRef]

97. Monsalve, Y.; Tosi, G.; Ruozi, B.; Belletti, D.; Vilella, A.; Zoli, M.; Vandelli, M.A.; Forni, F.; López, B.L.; Sierra, L. PEG-g-chitosan nanoparticles functionalized with the monoclonal antibody OX26 for brain drug targeting. Nanomedicine 2015, 10, 1735-1750. [CrossRef]

98. Cai, Q.; Wang, L.; Deng, G.; Liu, J.; Chen, Q.; Chen, Z. Systemic delivery to central nervous system by engineered PLGA nanoparticles. Am. J. Transl. Res. 2016, 8, 749.

99. Avnesh, K.; Sudesh, K.; Yadav, S.; Yadav, C. Biodegradable polymeric nanoparticles based drug delivery systems. Colloids Sur. B Biointerfaces 2010, 75, 1-18.

100. Halliday, A.J.; Cook, M.J. Polymer-based drug delivery devices for neurological disorders. CNS Neurol. Disord. Drug Targets 2009, 8, 205-221. [CrossRef] [PubMed]

101. Eslami, P.; Rossi, F.; Fedeli, S. Hybrid Nanogels: Stealth and Biocompatible Structures for Drug Delivery Applications. Pharmaceutics 2019, 11, 71. [CrossRef] [PubMed]

102. Chiellini, F.; Piras, A.M.; Errico, C.; Chiellini, E. Micro/nanostructured polymeric systems for biomedical and pharmaceutical applications. Nanomedicine 2008, 3, 367-393. [CrossRef] [PubMed]

103. Cheng, Q.; Feng, J.; Chen, J.; Zhu, X.; Li, F. Brain transport of neurotoxin-I with PLA nanoparticles through intranasal administration in rats: A microdialysis study. Biopharm. Drug Dispos. 2008, 29, 431-439. [CrossRef] [PubMed]

104. Saucier-Sawyer, J.K.; Deng, Y.; Seo, Y.E.; Cheng, C.J.; Zhang, J.; Quijano, E.; Saltzman, W.M. Systemic delivery of blood-brain barrier-targeted polymeric nanoparticles enhances delivery to brain tissue. J. Drug Target. 2015, 23, 736-749. [CrossRef] [PubMed]

105. Kubek, M.J.; Domb, A.J.; Veronesi, M.C. Attenuation of kindled seizures by intranasal delivery of neuropeptide-loaded nanoparticles. Neurotherapeutics 2009, 6, 359-371. [CrossRef]

106. Gan, C.W.; Feng, S.S. Transferrin-conjugated nanoparticles of poly (lactide)-D- $\alpha$-tocopheryl polyethylene glycol succinate diblock copolymer for targeted drug delivery across the blood-brain barrier. Biomaterials 2010, 31, 7748-7757. [CrossRef]

107. Xia, H.; Gao, X.; Gu, G.; Liu, Z.; Hu, Q.; Tu, Y.; Song, Q.; Yao, L.; Pang, Z.; Jiang, X. Penetratin-functionalized PEG-PLA nanoparticles for brain drug delivery. Int. J. Pharm. 2012, 436, 840-850. [CrossRef]

108. Song, E.; Gaudin, A.; King, A.R.; Seo, Y.E.; Suh, H.W.; Deng, Y.; Cui, J.; Tietjen, G.T.; Huttner, A.; Saltzman, W.M. Surface chemistry governs cellular tropism of nanoparticles in the brain. Nat. Commun. 2017, 8, 15322. [CrossRef]

109. Zheng, X.; Zhang, C.; Guo, Q.; Wan, X.; Shao, X.; Liu, Q.; Zhang, Q. Dual-functional nanoparticles for precise drug delivery to Alzheimer's disease lesions: Targeting mechanisms, pharmacodynamics and safety. Int. J. Pharm. 2017, 525, 237-248. [CrossRef]

110. Pan, L.; Zhou, J.; Ju, F.; Zhu, H. Intranasal delivery of $\alpha$-asarone to the brain with lactoferrin-modified mPEG-PLA nanoparticles prepared by premix membrane emulsification. Drug Deliv. Transl. Res. 2018, 8, 83-96. [CrossRef] [PubMed]

111. Shen, Y.; Cao, B.; Snyder, N.R.; Woeppel, K.M.; Eles, J.R.; Cui, X.T. ROS responsive resveratrol delivery from LDLR peptide conjugated PLA-coated mesoporous silica nanoparticles across the blood-brain barrier. J. Nanobiotechnol. 2018, 16, 13. [CrossRef] [PubMed] 
112. Tahara, K.; Miyazaki, Y.; Kawashima, Y.; Kreuter, J.; Yamamoto, H. Brain targeting with surface-modified poly (D, L-lactic-co-glycolic acid) nanoparticles delivered via carotid artery administration. Eur. J. Pharm. Biopharm. 2011, 77, 84-88. [CrossRef] [PubMed]

113. Gelperina, S.; Maksimenko, O.; Khalansky, A.; Vanchugova, L.; Shipulo, E.; Abbasova, K.; Berdiev, R.; Wohlfart, S.; Chepurnova, N.; Kreuter, J. Drug delivery to the brain using surfactant-coated poly (lactide-co-glycolide) nanoparticles: Influence of the formulation parameters. Eur. J. Pharm. Biopharm. 2010, 74, 157-163. [CrossRef] [PubMed]

114. Mittal, G.; Carswell, H.; Brett, R.; Currie, S.; Kumar, M.R. Development and evaluation of polymer nanoparticles for oral delivery of estradiol to rat brain in a model of Alzheimer's pathology. J. Control. Release 2011, 150, 220-228. [CrossRef]

115. Wang, Z.H.; Wang, Z.Y.; Sun, C.S.; Wang, C.Y.; Jiang, T.Y.; Wang, S.L. Trimethylated chitosan-conjugated PLGA nanoparticles for the delivery of drugs to the brain. Biomaterials 2010, 31, 908-915. [CrossRef]

116. Li, J.; Feng, L.; Fan, L.; Zha, Y.; Guo, L.; Zhang, Q.; Chen, J.; Pang, Z.; Wang, Y.; Jiang, X. Targeting the brain with PEG-PLGA nanoparticles modified with phage-displayed peptides. Biomaterials 2011, 32, 4943-4950. [CrossRef]

117. Sánchez-López, E.; Ettcheto, M.; Egea, M.A.; Espina, M.; Cano, A.; Calpena, A.C.; Camins, A.; Carmona, N.; Silva, A.M.; Souto, E.B. Memantine loaded PLGA PEGylated nanoparticles for Alzheimer's disease: In vitro and in vivo characterization. J. Nanobiotechnol. 2018, 16, 32. [CrossRef]

118. Chen, T.; Li, C.; Li, Y.; Yi, X.; Wang, R.; Lee, S.M.Y.; Zheng, Y. Small-sized mPEG-PLGA nanoparticles of Schisantherin A with sustained release for enhanced brain uptake and anti-parkinsonian activity. ACS Appl. Mater. Interfaces 2017, 9, 9516-9527. [CrossRef]

119. Huang, N.; Lu, S.; Liu, X.G.; Zhu, J.; Wang, Y.J.; Liu, R.T. PLGA nanoparticles modified with a BBB-penetrating peptide co-delivering $A \beta$ generation inhibitor and curcumin attenuate memory deficits and neuropathology in Alzheimer's disease mice. Oncotarget 2017, 8, 81001.

120. Chu, L.; Wang, A.; Ni, L.; Yan, X.; Song, Y.; Zhao, M.; Sun, K.; Mu, H.; Liu, S.; Wu, Z. Nose-to-brain delivery of temozolomide-loaded PLGA nanoparticles functionalized with anti-EPHA3 for glioblastoma targeting. Drug Deliv. 2018, 25, 1634-1641. [CrossRef] [PubMed]

121. Li, H.; Tong, Y.; Bai, L.; Ye, L.; Zhong, L.; Duan, X.; Zhu, Y. Lactoferrin functionalized PEG-PLGA nanoparticles of shikonin for brain targeting therapy of glioma. Int. J. Biol. Macromol. 2018, 107, 204-211. [CrossRef] [PubMed]

122. Barcia, E.; Boeva, L.; García-García, L.; Slowing, K.; Fernández-Carballido, A.; Casanova, Y.; Negro, S. Nanotechnology-based drug delivery of ropinirole for Parkinson's disease. Drug Deliv. 2017, 24, 1112-1123. [CrossRef] [PubMed]

123. Orunoğlu, M.; Kaffashi, A.; Pehlivan, S.B.; Şahin, S.; Söylemezoğlu, F.; Oğuz, K.K.; Mut, M. Effects of curcumin-loaded PLGA nanoparticles on the RG2 rat glioma model. Mater. Sci. Eng. C 2017, 78, 32-38. [CrossRef] [PubMed]

124. Zou, L.; Tao, Y.; Payne, G.; Do, L.; Thomas, T.; Rodriguez, J.; Dou, H. Targeted delivery of nano-PTX to the brain tumor-associated macrophages. Oncotarget 2017, 8, 6564. [CrossRef]

125. Kou, L.; Hou, Y.; Yao, Q.; Guo, W.; Wang, G.; Wang, M.; Fu, Q.; He, Z.; Ganapathy, V.; Sun, J. L-Carnitine-conjugated nanoparticles to promote permeation across blood-brain barrier and to target glioma cells for drug delivery via the novel organic cation/carnitine transporter OCTN2. Artif. Cells Nanomed. Biotechnol. 2018, 46, 1605-1616. [CrossRef]

126. Changyong, C.; Chae, S.Y.; Jae-Won, N. Thermosensitive poly(N-isopropylacrylamide)-b-poly(caprolactone) nanoparticles for efficient drug delivery system. Polymer 2006, 47, 4571-4580.

127. Rezaie, P.; Khoei, S.; Khoee, S.; Shirvalilou, S.; Mahdavi, S.R. Evaluation of combined effect of hyperthermia and ionizing radiation on cytotoxic damages induced by IUdR-loaded PCL-PEG-coated magnetic nanoparticles in spheroid culture of U87MG glioblastoma cell line. Int. J. Radiat. Biol. 2018, 94, 1027-1037. [CrossRef]

128. Irani, M.; Sadeghi, G.M.M.; Haririan, I. A novel biocompatible drug delivery system of chitosan/temozolomide nanoparticles loaded PCL-PU nanofibers for sustained delivery of temozolomide. Int. J. Biol. Macromol. 2017, 97, 744-751. [CrossRef]

129. Küçüktürkmen, B.; Devrim, B.; Saka, O.M.; Yilmaz, Ş.; Arsoy, T.; Bozkir, A. Co-delivery of pemetrexed and miR-21 antisense oligonucleotide by lipid-polymer hybrid nanoparticles and effects on glioblastoma cells. Drug Dev. Ind. Pharm. 2017, 43, 12-21. [CrossRef] 
130. Ahmad, N.; Ahmad, R.; Alam, M.A.; Ahmad, F.J. Quantification and brain targeting of eugenol-loaded surface modified nanoparticles through intranasal route in the treatment of cerebral ischemia. Drug Res. 2018, 68, 584-595. [CrossRef] [PubMed]

131. Irani, M.; Sadeghi, G.M.M.; Haririan, I. The sustained delivery of temozolomide from electrospun PCL-Diol-b-PU/gold nanocompsite nanofibers to treat glioblastoma tumors. Mater. Sci. Eng. C 2017, 75, 165-174. [CrossRef] [PubMed]

132. Varan, C.; Bilensoy, E. Cationic PEGylated polycaprolactone nanoparticles carrying post-operation docetaxel for glioma treatment. Beilstein J. Nanotechnol. 2017, 8, 1446-1456. [CrossRef] [PubMed]

133. Wilson, B.; Samanta, M.K.; Santhi, K.; Kumar, K.P.; Paramakrishnan, N.; Suresh, B. Targeted delivery of tacrine into the brain with polysorbate 80-coated poly(n-butylcyanoacrylate) nanoparticles. Eur. J. Pharm. Biopharm. 2008, 70, 75-84. [CrossRef]

134. Petri, B.; Bootz, A.; Khalansky, A.; Hekmatara, T.; Muller, R.; Uhl, R.; Kreuter, J.; Gelperina, S. Chemotherapy of brain tumour using doxorubicin bound to surfactant-coated poly(butyl cyanoacrylate) nanoparticles: Revisiting the role of surfactants. J. Control. Release 2007, 117, 51-58. [CrossRef]

135. Mulik, R.S.; Mönkkönen, J.; Juvonen, R.O.; Mahadik, K.R.; Paradkar, A.R. ApoE3 mediated poly (butyl) cyanoacrylate nanoparticles containing curcumin: Study of enhanced activity of curcumin against beta amyloid induced cytotoxicity using in vitro cell culture model. Mol. Pharm. 2010, 7, 815-825. [CrossRef]

136. Kurakhmaeva, K.B.; Voronina, T.A.; Kapica, I.G.; Kreuter, J.; Nerobkova, L.N.; Seredenin, S.B.; Balabanian, V.Y.; Alyautdin, R.N. Antiparkinsonian effect of nerve growth factor adsorbed on polybutylcyanoacrylate nanoparticles coated with polysorbate-80. Bull. Exp. Biol. Med. 2008, 145, 259-262. [CrossRef]

137. Kreuter, J.; Petrov, V.E.; Kharkevich, D.A.; Alyautdin, R.N. Infuence of the type of surfactant on the analgesic effects induced by the peptide dalargin after its delivery across the blood brain barrier using surfactant-coated nanoparticles. J. Control. Release 1997, 49, 81-87. [CrossRef]

138. Kreuter, J.; Ramge, P.; Petrov, V.; Hamm, S.; Gelperina, S.E.; Engelhardt, B.; Alyautdin, R.; Von Briesen, H.; Begley, D.J. Direct evidence that polysorbate-80-coated poly (butylcyanoacrylate) nanoparticles deliver drugs to the CNS via specific mechanisms requiring prior binding of drug to the nanoparticles. Pharm. Res. 2003, 20, 409-416. [CrossRef]

139. Carradori, D.; Balducci, C.; Re, F.; Brambilla, D.; Le Droumaguet, B.; Flores, O.; Gaudin, A.; Mura, S.; Forloni, G.; Ordoñez-Gutierrez, L. Antibody-functionalized polymer nanoparticle leading to memory recovery in Alzheimer's disease-like transgenic mouse model. Nanomed. Nanotechnol. Biol. Med. 2018, 14, 609-618. [CrossRef]

140. Ramalho, M.; Sevin, E.; Gosselet, F.; Lima, J.; Coelho, M.; Loureiro, J.; Pereira, M. Receptor-mediated PLGA nanoparticles for glioblastoma multiforme treatment. Int. J. Pharm. 2018, 545, 84-92. [CrossRef] [PubMed]

141. Gajbhiye, K.R.; Gajbhiye, V.; Siddiqui, I.A.; Pilla, S.; Soni, V. Ascorbic acid tethered polymeric nanoparticles enable efficient brain delivery of galantamine: An in vitro-in vivo study. Sci. Rep. 2017, 7, 11086. [CrossRef] [PubMed]

142. Guo, B.; Sheng, Z.; Hu, D.; Lin, X.; Xu, S.; Liu, C.; Zheng, H.; Liu, B. Biocompatible conjugated polymer nanoparticles for highly efficient photoacoustic imaging of orthotopic brain tumors in the second near-infrared window. Mater. Horiz. 2017, 4, 1151-1156. [CrossRef]

143. Kuo, Y.C.; Tsai, H.C. Rosmarinic acid-and curcumin-loaded polyacrylamide-cardiolipin-poly (lactide-co-glycolide) nanoparticles with conjugated $83-14$ monoclonal antibody to protect $\beta$-amyloid-insulted neurons. Mater. Sci. Eng. C 2018, 91, 445-457. [CrossRef] [PubMed]

144. Ulbrich, K.; Knobloch, T.; Kreuter, J. Targeting the insulin receptor: Nanoparticles for drug delivery across the blood-brain barrier (BBB). J. Drug Target. 2011, 19, 125-132. [CrossRef] [PubMed]

145. Ruan, C.; Liu, L.; Lu, Y.; Zhang, Y.; He, X.; Chen, X.; Zhang, Y.; Chen, Q.; Guo, Q.; Sun, T. Substance P-modified human serum albumin nanoparticles loaded with paclitaxel for targeted therapy of glioma. Acta Pharm. Sin. B 2018, 8, 85-96. [CrossRef]

146. Wong, L.R.; Ho, P.C. Role of serum albumin as a nanoparticulate carrier for nose-to-brain delivery of R-flurbiprofen: Implications for the treatment of Alzheimer's disease. J. Pharm. Pharmacol. 2018, 70, 59-69. [CrossRef]

147. Liang, J.; Gao, C.; Zhu, Y.; Ling, C.; Wang, Q.; Huang, Y.; Qin, J.; Wang, J.; Lu, W.; Wang, J. Natural Brain Penetration Enhancer-Modified Albumin Nanoparticles for Glioma Targeting Delivery. ACS Appl. Mater. Interfaces 2018, 10, 30201-30213. [CrossRef] 
148. Kaur, A.; Jain, S.; Tiwary, A.K. Mannan-coated gelatin nanoparticles for sustained and targeted delivery of didanosine: In vitro and in vivo evaluation. Acta Pharm. 2008, 58, 61-74. [CrossRef]

149. Tian, X.H.; Wei, F.; Wang, T.X.; Wang, P.; Lin, X.N.; Wang, J.; Wang, D.; Ren, L. In vitro and in vivo studies on gelatin-siloxane nanoparticles conjugated with SynB peptide to increase drug delivery to the brain. Int. J. Nanomed. 2012, 7, 1031.

150. Nejat, H.; Rabiee, M.; Varshochian, R.; Tahriri, M.; Jazayeri, H.; Rajadas, J.; Ye, H.; Cui, Z.; Tayebi, L. Preparation and characterization of cardamom extract-loaded gelatin nanoparticles as effective targeted drug delivery system to treat glioblastoma. React. Funct. Polym. 2017, 120, 46-56. [CrossRef]

151. Wang, X.; Chi, N.; Tang, X. Preparation of estradiol chitosan nanoparticles for improving nasal absorption and brain targeting. Eur. J. Pharm. Biopharm. 2008, 70, 735-740. [CrossRef] [PubMed]

152. Aktaş, Y.; Yemisci, M.; Andrieux, K.; Gürsoy, R.N.; Alonso, M.J.; Fernandez-Megia, E.; Novoa-Carballal, R.; Quiñoá, E.; Riguera, R.; Sargon, M.F. Development and brain delivery of chitosan-PEG nanoparticles functionalized with the monoclonal antibody OX26. Bioconjug. Chem. 2005, 16, 1503-1511. [CrossRef] [PubMed]

153. Wang, Y.Y.; Lai, S.K.; Suk, J.S.; Pace, A.; Cone, R.; Hanes, J. Addressing the PEG mucoadhesivity paradox to engineer nanoparticles that "slip" through the human mucus barrier. Angew. Chem. Int. Ed. 2008, 47, 9726-9729. [CrossRef]

154. Trapani, A.; De Giglio, E.; Cafagna, D.; Denora, N.; Agrimi, G.; Cassano, T.; Gaetani, S.; Cuomo, V.; Trapani, G. Characterization and evaluation of chitosan nanoparticles for dopamine brain delivery. Int. J. Pharm. 2011, 419, 296-307. [CrossRef]

155. Tammam, S.N.; Azzazy, H.M.; Lamprecht, A. Nuclear and Cytoplasmic Delivery of Lactoferrin in Glioma using Chitosan Nanoparticles: Cellular Location Dependent-Action of Lactoferrin. Eur. J. Pharm. Biopharm. 2018, 129, 74-79. [CrossRef]

156. Gu, J.; Al-Bayati, K.; Ho, E.A. Development of antibody-modified chitosan nanoparticles for the targeted delivery of siRNA across the blood-brain barrier as a strategy for inhibiting HIV replication in astrocytes. Drug Deliv. Transl. Res. 2017, 7, 497-506. [CrossRef]

157. Gholami, L.; Tafaghodi, M.; Abbasi, B.; Daroudi, M.; Kazemi Oskuee, R. Preparation of superparamagnetic iron oxide/doxorubicin loaded chitosan nanoparticles as a promising glioblastoma theranostic tool. J. Cell. Physiol. 2019, 234, 1547-1559. [CrossRef]

158. Xu, Y.; Asghar, S.; Yang, L.; Li, H.; Wang, Z.; Ping, Q.; Xiao, Y. Lactoferrin-coated polysaccharide nanoparticles based on chitosan hydrochloride/hyaluronic acid/PEG for treating brain glioma. Carbohydr. Polym. 2017, 157, 419-428. [CrossRef]

159. Agrawal, P.; Singh, R.P.; Kumari, L.; Sharma, G.; Koch, B.; Rajesh, C.V.; Mehata, A.K.; Singh, S.; Pandey, B.L.; Muthu, M.S. TPGS-chitosan cross-linked targeted nanoparticles for effective brain cancer therapy. Mater. Sci. Eng. C 2017, 74, 167-176. [CrossRef]

160. Singh, P.K.; Srivastava, A.K.; Dev, A.; Kaundal, B.; Choudhury, S.R.; Karmakar, S. 1, 3ß-Glucan anchored, paclitaxel loaded chitosan nanocarrier endows enhanced hemocompatibility with efficient anti-glioblastoma stem cells therapy. Carbohydr. Polym. 2018, 180, 365-375. [CrossRef] [PubMed]

161. Raj, R.; Wairkar, S.; Sridhar, V.; Gaud, R. Pramipexole dihydrochloride loaded chitosan nanoparticles for nose to brain delivery: Development, characterization and in vivo anti-Parkinson activity. Int. J. Biol. Macromol. 2018, 109, 27-35. [CrossRef] [PubMed]

162. Jahromi, L.P.; Panah, F.M.; Azadi, A.; Ashrafi, H. A mechanistic investigation on methotrexate-loaded chitosan-based hydrogel nanoparticles intended for CNS drug delivery: Trojan horse effect or not? Int. J. Biol. Macromol. 2019, 125, 785-790. [CrossRef] [PubMed]

163. Liu, Y.; Li, Y.; Keskin, D.; Shi, L. Poly ( $\beta$-Amino Esters): Synthesis, Formulations, and Their Biomedical Applications. Adv. Healthc. Mater. 2019, 8, 1801359.

164. Ashrafizadeh, M.; Ahmadi, Z.; Kotla, N.G.; Afshar, E.G.; Samarghandian, S.; Mandegary, A.; Pardakhty, A.; Mohammadinejad, R.; Sethi, G. Nanoparticles Targeting STATs in Cancer Therapy. Cells 2019, 8, 1158. [CrossRef] [PubMed]

165. Tavakol, S.; Ashrafizadeh, M.; Deng, S.; Azarian, M.; Abdoli, A.; Motavaf, M.; Poormoghadam, D.; Khanbabaei, H.; Ghasemipour Afshar, E.; Mandegary, A. Autophagy Modulators: Mechanistic Aspects and Drug Delivery Systems. Biomolecules 2019, 9, 530. [CrossRef] [PubMed] 
166. Mohammadinejad, R.; Dadashzadeh, A.; Moghassemi, S.; Ashrafizadeh, M.; Dehshahri, A.; Pardakhty, A.; Sassan, H.A.; Sohrevardi, S.M.; Mandegary, A. Shedding light on gene therapy: Carbon dots for the minimally invasive image-guided delivery of plasmids and noncoding RNAs. J. Adv. Res. 2019, 18, 81-93. [CrossRef]

167. Ashrafizadeh, M.; Ahmadi, Z.; Mohammadinejad, R.; Farkhondeh, T.; Samarghandian, S. Nano-soldiers Ameliorate Silibinin Delivery: A Review Study. Curr. Drug Deliv. 2019. [CrossRef]

168. Ashrafizadeh, M.; Ahmadi, Z.; Mohamadi, N.; Zarrabi, A.; Abasi, S.; Dehghannoudeh, G.; Tamaddondoust, R.N.; Khanbabaei, H.; Mohammadinejad, R.; Thakur, V.K. Chitosan-based advanced materials for docetaxel and paclitaxel delivery: Recent advances and future directions in cancer theranostics. Int. J. Biol. Macromol. 2020, 145, 282-300. [CrossRef]

169. Dehshahri, A.; Ashrafizadeh, M.; Afshar, E.G.; Pardakhty, A.; Mandegary, A.; Mohammadinejad, R.; Sethi, G. Topoisomerase inhibitors: Pharmacology and emerging nanoscale delivery systems. Pharmacol. Res. 2020, 151, 104551. [CrossRef]

170. Dehshahri, A.; Alhashemi, S.H.; Jamshidzadeh, A.; Sabahi, Z.; Samani, S.M.; Sadeghpour, H.; Mohazabieh, E.; Fadaei, M. Comparison of the effectiveness of polyethylenimine, polyamidoamine and chitosan in transferring plasmid encoding interleukin-12 gene into hepatocytes. Macromol. Res. 2013, 21, 1322-1330. [CrossRef]

171. Dehshahri, A.; Sadeghpour, H.; Oskuee, R.K.; Fadaei, M.; Sabahi, Z.; Alhashemi, S.H.; Mohazabieh, E. Interleukin-12 plasmid DNA delivery using 1-thyroxine-conjugated polyethylenimine nanocarriers. J. Nanopart. Res. 2014, 16, 2423. [CrossRef]

172. Oskuee, R.K.; Dehshahri, A.; Shier, T.; Ramezani, M. Modified polyethylenimine: Self assemble nanoparticle forming polymer for pDNA delivery. Iran. J. Basic Med. Sci. 2008, 11, 33-40.

173. Sahoo, S.K.; Labhasetwar, V. Biodegradable PLGA/PLA Nanoparticles for Anticancer Therapy; CRC Press: Boca Raton, FL, USA, 2007.

174. Mirhadi, E.; Rezaee, M.; Malaekeh-Nikouei, B. Nano strategies for berberine delivery, a natural alkaloid of Berberis. Biomed. Pharmacother. 2018, 104, 465-473. [CrossRef] [PubMed]

175. Dechy-Cabaret, O.; Martin-Vaca, B.; Bourissou, D. Controlled ring-opening polymerization of lactide and glycolide. Chem. Rev. 2004, 104, 6147-6176. [CrossRef]

176. Ueda, H.; Tabata, Y. Polyhydroxyalkanonate derivatives in current clinical applications and trials. Adv. Drug Deliv. Rev. 2003, 55, 501-518. [CrossRef]

177. Anderson, J.M.; Shive, M.S. Biodegradation and biocompatibility of PLA and PLGA microspheres. Adv. Drug Deliv. Rev. 2012, 64, 72-82. [CrossRef]

178. Hu, K.; Li, J.; Shen, Y.; Lu, W.; Gao, X.; Zhang, Q.; Jiang, X. Lactoferrin-conjugated PEG-PLA nanoparticles with improved brain delivery: In vitro and in vivo evaluations. J. Control. Release 2009, 134, 55-61. [CrossRef]

179. Wang, Y.; Li, S.Y.; Shen, S.; Wang, J. Protecting neurons from cerebral ischemia/reperfusion injury via nanoparticle-mediated delivery of an siRNA to inhibit microglial neurotoxicity. Biomaterials 2018, 161, 95-105. [CrossRef]

180. Zhu, X.; Pang, Z.; Shen, S. Tumor Microenvironment Responsive ACPP-Conjugated Micelles for Targeted Treatment of Brain Glioma. Part. Part. Syst. Charact. 2017, 34, 1600201. [CrossRef]

181. Calzoni, E.; Cesaretti, A.; Polchi, A.; Di Michele, A.; Tancini, B.; Emiliani, C. Biocompatible polymer nanoparticles for drug delivery applications in cancer and neurodegenerative disorder therapies. J. Funct. Biomater. 2019, 10, 4. [CrossRef] [PubMed]

182. Bors, L.A.; Erdő, F. Overcoming the Blood-Brain Barrier. Challenges and Tricks for CNS Drug Delivery. Sci. Pharm. 2019, 87, 6. [CrossRef]

183. Muthu, M.S. Nanoparticles based on PLGA and its co-polymer: An overview. Asian J. Pharm. 2009, 3, 266-273. [CrossRef]

184. Cheng, J.; Ling, B.; Hong, W.; Zenghui, T.; Guozhen, G.; Jingyuan, C. Cellular uptake and radiosensitization of SR-2508 loaded PLGA nanoparticles. J. Nanopart. Res. 2008, 10, 1045-1052.

185. Dong, Y.; Feng, S.S. Poly(D,L-lactide-co-glycolide) (PLGA) nanoparticles prepared by high pressure homogenization for paclitaxel chemotherapy. Int. J. Pharm. 2007, 342, 208-214. [CrossRef]

186. Sarcan, E.T.; Silindir-Gunay, M.; Ozer, A.Y. Theranostic polymeric nanoparticles for nir imaging and photodynamic therapy. Int. J. Pharm. 2018, 551, 329-338. [CrossRef]

187. Huo, X.; Zhang, Y.; Jin, X.; Li, Y.; Zhang, L. A novel synthesis of selenium nanoparticles encapsulated PLGA nanospheres with curcumin molecules for the inhibition of amyloid $\beta$ aggregation in Alzheimer's disease. J. Photochem. Photobiol. B Biol. 2019, 190, 98-102. [CrossRef] 
188. Sahana, D.K.; Mittal, G.; Bhardwaj, V.; Kumar, M.N. PLGA nanoparticles for oral delivery of hydrophobic drugs: influence of organic solvent on nanoparticle formation and release behavior in vitro and in vivo using estradiol as a model drug. Pharm. Sci. 2008, 97, 1530-1542. [CrossRef]

189. Esmaeili, F.; Ghahremani, M.H.; Ostad, S.N.; Atyabi, F.; Seyedabadi, M.; Malekshahi, M.R.; Amini, M.; Dinarvand, R. Folate-receptor-targeted delivery of docetaxel nanoparticles prepared by PLGA-PEG-folate conjugate. J. Drug Target. 2008, 16, 415-423. [CrossRef]

190. Guo, L.; Zhang, H.; Wang, F.; Liu, P.; Wang, Y.; Xia, G.; Liu, R.; Li, X.; Yin, H.; Jiang, H. Targeted multidrug-resistance reversal in tumor based on PEG-PLL-PLGA polymer nano drug delivery system. Int. J. Nanomed. 2015, 10, 4535.

191. Salatin, S.; Barar, J.; Barzegar-Jalali, M.; Adibkia, K.; Kiafar, F.; Jelvehgari, M. An Alternative Approach for Improved Entrapment Efficiency of Hydrophilic Drug Substance in PLGA Nanoparticles by Interfacial Polymer Deposition Following Solvent Displacement. Jundishapur J. Nat. Pharm. Prod. 2018, 13, e12873. [CrossRef]

192. Schwendeman, S.P. Recent advances in the stabilization of proteins encapsulated in injectable PLGA delivery systems. Crit. Rev. Ther. Drug Carr. Syst. 2002, 19, 73-98. [CrossRef] [PubMed]

193. Budhian, A.; Siegel, S.J.; Winey, K.I. Production of haloperidol-loaded PLGA nanoparticles for extended controlled drug release of haloperidol. J. Microencapsul. 2005, 22, 773-785. [CrossRef] [PubMed]

194. Chen, Y.C.; Hsieh, W.Y.; Lee, W.F.; Zeng, D.T. Effects of surface modification of PLGA-PEG-PLGA nanoparticles on loperamide delivery efficiency across the blood-brain barrier. J. Biomater. Appl. 2013, 27, 909-922. [CrossRef]

195. Guo, J.; Gao, X.; Su, L.; Xia, H.; Gu, G.; Pang, Z.; Jiang, X.; Yao, L.; Chen, J.; Chen, H. Aptamer-functionalized PEG-PLGA nanoparticles for enhanced anti-glioma drug delivery. Biomaterials 2011, 32, 8010-8020. [CrossRef]

196. Joshi, S.A.; Chavhan, S.S.; Sawant, K.K. Rivastigmine-loaded PLGA and PBCA nanoparticles: Preparation, optimization, characterization, in vitro and pharmacodynamic studies. Eur. J. Pharm. Biopharm. 2010, 76, 189-199. [CrossRef]

197. Hanumantha Rao Madala, S.R.P.; Ali-Osman, F.; Zhang, R.; Srivenugopal, K.S. Brain-and brain tumor-penetrating disulfiram nanoparticles: Sequence of cytotoxic events and efficacy in human glioma cell lines and intracranial xenografts. Oncotarget 2018, 9, 3459.

198. Chai, Z.; Hu, X.; Wei, X.; Zhan, C.; Lu, L.; Jiang, K.; Su, B.; Ruan, H.; Ran, D.; Fang, R.H. A facile approach to functionalizing cell membrane-coated nanoparticles with neurotoxin-derived peptide for brain-targeted drug delivery. J. Control. Release 2017, 264, 102-111. [CrossRef]

199. Cipitria, A.; Skelton, A.; Dargaville, T.; Dalton, P.; Hutmacher, D. Design, fabrication and characterization of PCL electrospun scaffolds-A review. J. Mater. Chem. 2011, 21, 9419-9453. [CrossRef]

200. Croisier, F.; Duwez, A.S.; Jérôme, C.; Léonard, A.; Van Der Werf, K.; Dijkstra, P.J.; Bennink, M.L. Mechanical testing of electrospun PCL fibers. Acta Biomater. 2012, 8, 218-224. [CrossRef]

201. Leung, M.K.; Hagemeyer, C.E.; Johnston, A.P.; Gonzales, C.; Kamphuis, M.M.; Ardipradja, K.; Such, G.K.; Peter, K.; Caruso, F. Bio-Click Chemistry: Enzymatic Functionalization of PEGylated Capsules for Targeting Applications. Angew. Chem. Int. Ed. 2012, 51, 7132-7136. [CrossRef] [PubMed]

202. Domingos, M.; Dinucci, D.; Cometa, S.; Alderighi, M.; Bartolo, P.J.; Chiellini, F. Polycaprolactone Scaffolds Fabricated via Bioextrusion for Tissue Engineering Applications. Int. J. Biomater. 2009, 2009, 239643. [CrossRef] [PubMed]

203. Fabbri, P.; Bondioli, F.; Messori, M.; Bartoli, C.; Dinucci, D.; Chiellini, F. Porous scaffolds of polycaprolactone reinforced with in situ generated hydroxyapatite for bone tissue engineering. J. Mater. Sci. Mater. Med. 2010, 21, 343-351. [CrossRef] [PubMed]

204. Couvreur, P.; Kante, B.; Roland, M.; Guiot, P.; Bauduin, P.; Speiser, P. Polycyanoacrylate nanocapsules as potential lysosomotropic carriers: Preparation, morphological and sorptive properties. J. Pharm. Pharmacol. 1979, 31, 331-332. [CrossRef] [PubMed]

205. Vauthier, C.; Dubernet, C.; Fattal, E.; Pintoalphandary, H.; Couvreur, P. Drug delivery to resistant tumors: The potential of poly(alkyl cyanoacrylate) nanoparticles. J. Control. Release 2003, 93, 151-160. [CrossRef] [PubMed]

206. Mura, S.; Fattal, E.; Nicolas, J. From poly (alkyl cyanoacrylate) to squalene as core material for the design of nanomedicines. J. Drug Target. 2019, 27, 470-501. [CrossRef] 
207. Blagosklonny, M.V. Targeting cancer cells by exploiting their resistance. Trends Mol. Med. 2003, 9, $307-312$. [CrossRef]

208. Galmarini, C.M.; Galmarini, F.C. Multidrug resistance in cancer therapy: Role of the microenvironment. Curr. Opin. Investig. Drugs 2003, 4, 1416-1421.

209. Krishna, R.; Mayer, L.D. Multidrug resistance (MDR) in cancer. Mechanisms, reversal using modulators of MDR and the role of MDR modulators in influencing the pharmacokinetics of anticancer drugs. Eur. J. Pharm. Sci. 2000, 11, 265-283. [CrossRef]

210. Ambruosi, A.; Khalansky, A.S.; Yamamoto, H.; Gelperina, S.E.; Begley, D.J.; Kreuter, J. Biodistribution of polysorbate 80-coated doxorubicin-loaded [14C]-poly(butyl cyanoacrylate) nanoparticles after intravenous administration to glioblastoma-bearing rats. J. Drug Target. 2006, 14, 97-105. [CrossRef]

211. Schroeder, U.; Sommerfeld, P.; Sabel, B.A. Efficacy of oral dalargin-loaded nanoparticle delivery across the blood-brain barrier. Peptides 1998, 19,777-780. [CrossRef]

212. Gao, K.; Jiang, X. Influence of particle size on transport of methotrexate across blood brain barrier by polysorbate 80-coated polybutylcyanoacrylate nanoparticles. Int. J. Pharm. 2006, 310, 213-219. [CrossRef] [PubMed]

213. Alyautdin, R.N.; Petrov, V.E.; Langer, K.; Berthold, A.; Kharkevich, D.A.; Kreuter, J. Delivery of loperamide across the blood-brain barrier with polysorbate 80-coated polybutylcyanoacrylate nanoparticles. Pharm. Res. 1997, 14, 325-328. [CrossRef] [PubMed]

214. Alyautdin, R.N.; Tezikov, E.B.; Ramge, P.; Kharkevich, D.A.; Begley, D.J.; Kreuter, J. Significant entry of tubocurarine into the brain of rats by adsorption to polysorbate 80-coated polybutylcyanoacrylate nanoparticles: An in situ brain perfusion study. J. Microencapsul. 1998, 15, 67-74. [CrossRef]

215. Das, D.; Lin, S. Double-coated poly (butylcynanoacrylate) nanoparticulate delivery systems for brain targeting of dalargin via oral administration. J. Pharm. Sci. 2005, 94, 1343-1353. [CrossRef]

216. Ambruosi, A.; Gelperina, S.; Khalansky, A.; Tanski, S.; Theisen, A.; Kreuter, J. Influence of surfactants, polymer and doxorubicin loading on the anti-tumour effect of poly(butyl cyanoacrylate) nanoparticles in a rat glioma model. J. Microencapsul. 2006, 23, 582-592. [CrossRef]

217. Gulyaev, A.E.; Gelperina, S.E.; Skidan, I.N.; Antropov, A.S.; Kivman, G.Y.; Kreuter, J. Significant transport of doxorubicin into the brain with polysorbate 80-coated nanoparticles. Pharm. Res. 1999, 16, 1564-1569. [CrossRef]

218. Kreuter, J.; Shamenkov, D.; Petrov, V.; Ramge, P.; Cychutek, K.; Koch-Brandt, C.; Alyautdin, R. Apolipoprotein-mediated transport of nanoparticle-bound drugs across the blood-brain barrier. J. Drug Target. 2002, 10, 317-325. [CrossRef]

219. Yamamoto, H.; Bootz, A.; Kreuter, J. Preparation of temozolomideloaded poly(butyl cyanoacrylate) nanoparticle for chemotherapy of brain tumor. In Proceedings of the 15th International Symposium on Microencapsulation, Parma, Italy, 18-21 September 2005; pp. 439-440.

220. Wang, C.X.; Huang, L.S.; Hou, L.B.; Jiang, L.; Yan, Z.T.; Wang, Y.L.; Chen, Z.L. Antitumor effects of polysorbate-80 coated gemcitabine polybutylcyanoacrylate nanoparticles in vitro and its pharmacodynamics in vivo on C6 glioma cells of a brain tumor model. Brain Res. 2009, 1261, 91-99. [CrossRef]

221. Calvo, P.; Gouritin, B.; Brigger, I.; Lasmezas, C.; Deslys, J.; Williams, A.; Andreux, J.P.; Dormont, D.; Couvreur, P. PEGylated polycyanoacrylate nanoparticles as vector for drug delivery in prion diseases. J. Neurosci. Methods 2001, 111, 151-155. [CrossRef]

222. Kizelsztein, P.; Ovadia, H.; Garbuzenko, O.; Sigal, A.; Barenholz, Y. Pegylated nanoliposomes remote-loaded with the antioxidant tempamine ameliorate experimental autoimmune encephalomyelitis. J. Neuroimmunol. 2009, 213, 20-25. [CrossRef] [PubMed]

223. Lu, W.; Tan, Y.Z.; Hu, K.L.; Jiang, X.G. Cationic albumin conjugated pegylated nanoparticle with its transcytosis ability and little toxicity against blood-brain barrier. Int. J. Pharm. 2005, 295, 247-260. [CrossRef] [PubMed]

224. Lu, W.; Wan, J.; She, Z.; Jiang, X. Brain delivery property and accelerated blood clearance of cationic albumin conjugated pegylated nanoparticle. J. Control. Release 2007, 118, 38-53. [CrossRef] [PubMed]

225. Calvo, P.; Gouritin, B.; Chacun, H.; Desmaele, D.; D’Angelo, J.; Noel, J.P.; Georgin, D.; Fattal, E.; Andreux, J.P.; Couvreur, P. Long-circulating PEGylated polycyanoacrylate nanoparticles as new drug carrier for brain delivery. Pharm. Res. 2001, 18, 1157-1166. [CrossRef] 
226. Olivier, J.C.; Fenart, L.; Chauvet, R.; Pariat, C.; Cecchelli, R.; Couet, W. Indirect evidence that drug brain targeting using polysorbate 80-coated polybutylcyanoacrylate nanoparticles is related to toxicity. Pharm. Res. 1999, 16, 1836-1842. [CrossRef]

227. Vauthier, C.; Labarre, D.; Ponchel, G. Design aspects of poly(alkylcyanoacrylate) nanoparticles for drug delivery. J. Drug Target. 2007, 15, 641-663. [CrossRef]

228. Kratz, F. Albumin as a drug carrier: Design of prodrugs, drug conjugates and nanoparticles. J. Control. Release 2008, 132, 171-183. [CrossRef]

229. Zensi, A.; Begley, D.; Pontikis, C.; Legros, C.; Mihoreanu, L.; Wagner, S.; Buchel, C.; von Briesen, H.; Kreuter, J. Albumin nanoparticles targeted with Apo E enter the CNS by transcytosis and are delivered to neurones. J. Control. Release 2009, 137, 78-86. [CrossRef]

230. Tosi, G.; Costantino, L.; Rivasi, F.; Ruozi, B.; Leo, E.; Vergoni, A.V.; Tacchi, R.; Bertolini, A.; Vandelli, M.A.; Forni, F. Targeting the central nervous system: In vivo experiments with peptide-derivatized nanoparticles loaded with Loperamide and Rhodamine-123. J. Control. Release 2007, 122, 1-9. [CrossRef]

231. Dadparvar, M.; Wagner, S.; Wien, S.; Kufleitner, J.; Worek, F.; von Briesen, H.; Kreuter, J. HI 6 human serum albumin nanoparticles-Development and transport over an in vitro blood-brain barrier model. Toxicol. Lett. 2011, 206, 60-66. [CrossRef]

232. Wagner, S.; Zensi, A.; Wien, S.L.; Tschickardt, S.E.; Maier, W.; Vogel, T.; Worek, F.; Pietrzik, C.U.; Kreuter, J.; Von Briesen, H. Uptake mechanism of ApoE-modified nanoparticles on brain capillary endothelial cells as a blood-brain barrier model. PLoS ONE 2012, 7, e32568. [CrossRef] [PubMed]

233. Michaelis, K.; Hoffmann, M.M.; Dreis, S.; Herbert, E.; Alyautdin, R.N.; Michaelis, M.; Kreuter, J.; Langer, K. Covalent linkage of apolipoprotein e to albumin nanoparticles strongly enhances drug transport into the brain. J. Pharmacol. Exp. Ther. 2006, 317, 1246-1253. [CrossRef] [PubMed]

234. Pour, M.M.; Saberi-Riseh, R.; Mohammadinejad, R.; Hosseini, A. Nano-Encapsulation of Plant Growth-Promoting Rhizobacteria and Their Metabolites Using Alginate-Silica Nanoparticles and Carbon Nanotube Improves UCB1 Pistachio Micropropagation. J. Microbiol. Biotechnol. 2019, 29, 1096-1103. [PubMed]

235. Pour, M.M.; Saberi-Riseh, R.; Mohammadinejad, R.; Hosseini, A. Investigating the formulation of alginate-gelatin encapsulated Pseudomonas fluorescens (VUPF5 and T17-4 strains) for controlling Fusarium solani on potato. Int. J. Biol. Macromol. 2019, 133, 603-613. [CrossRef]

236. Gorgieva, S.; Kokol, V. Collagen-vs. gelatine-based biomaterials and their biocompatibility: Review and perspectives. In Biomaterials Applications for Nanomedicine; InTech: London, UK, 2011.

237. Lee, B.H.; Lum, N.; Seow, L.Y.; Lim, P.Q.; Tan, L.P. Synthesis and characterization of types a and $b$ gelatin methacryloyl for bioink applications. Materials 2016, 9, 797. [CrossRef]

238. Lee, B.H.; Shirahama, H.; Cho, N.J.; Tan, L.P. Efficient and controllable synthesis of highly substituted gelatin methacrylamide for mechanically stiff hydrogels. RSC Adv. 2015, 5, 106094-106097. [CrossRef]

239. Lee, B.H.; Shirahama, H.; Kim, M.H.; Lee, J.H.; Cho, N.J.; Tan, L.P. Colloidal templating of highly ordered gelatin methacryloyl-based hydrogel platforms for three-dimensional tissue analogues. NPG Asia Mater. 2017, 9, e412. [CrossRef]

240. Rose, J.; Pacelli, S.; Haj, A.; Dua, H.; Hopkinson, A.; White, L.; Rose, F. Gelatin-based materials in ocular tissue engineering. Materials 2014, 7, 3106-3135. [CrossRef]

241. Shirahama, H.; Lee, B.H.; Tan, L.P.; Cho, N.J. Precise tuning of facile one-pot gelatin methacryloyl (GelMA) synthesis. Sci. Rep. 2016, 6, 31036. [CrossRef]

242. Chiellini, E.; Cinelli, P.; Grillo Fernandes, E.; Kenawy el, R.S.; Lazzeri, A. Gelatin-based blends and composites. Morphological and thermal mechanical characterization. Biomacromolecules 2001, 2, 806-811. [CrossRef]

243. Foox, M.; Zilberman, M. Drug delivery from gelatin-based systems. Expert Opin. Drug Deliv. 2015, 12, 1547-1563. [CrossRef] [PubMed]

244. Chen, J.C.; Li, L.M.; Gao, J.Q. Biomaterials for local drug delivery in central nervous system. Int. J. Pharm. 2019, 560, 92-100. [CrossRef] [PubMed]

245. Doostmohammadi, M.; Ameri, A.; Mohammadinejad, R.; Dehghannoudeh, N.; Banat, I.M.; Ohadi, M.; Dehghannoudeh, G. Hydrogels For Peptide Hormones Delivery: Therapeutic And Tissue Engineering Applications. Drug Des. Dev. Ther. 2019, 13, 3405-3418. [CrossRef] [PubMed]

246. Hassanzadeh Davarani, F.; Ashrafizadeh, M.; Saberi Riseh, R. Antifungal nanoparticles reduce aflatoxin contamination in pistachio. PHJ 2018, 1, 25-33. 
247. Hombach, J.; Bernkop-Schnurch, A. Chitosan solutions and particles: Evaluation of their permeation enhancing potential on MDCK cells used as blood brain barrier model. Int. J. Pharm. 2009, 376, 104-109. [CrossRef]

248. Nagpal, K.; Singh, S.K.; Mishra, D.N. Chitosan nanoparticles: A promising system in novel drug delivery. Chem. Pharm. Bull. 2010, 58, 1423-1430. [CrossRef]

249. De Campos, A.M.; Sanchez, A.; Alonso, M.J. Chitosan nanoparticles: A new vehicle for the improvement of the delivery of drugs to the ocular surface. Application to cyclosporin A. Int. J. Pharm. 2001, 224, 159-168. [CrossRef]

250. Mistry, A.; Stolnik, S.; Illum, L. Nanoparticles for direct nose-to-brain delivery of drugs. Int. J. Pharm. 2009, 379, 146-157. [CrossRef]

251. Thorne, R.G.; Frey, W.H. Delivery of neurotrophic factors to the central nervous system. Clin. Pharmacokinet. 2001, 40, 907-946. [CrossRef]

252. Illum, L.; Farraj, N.F.; Davis, S.S. Chitosan as novel nasal delivery system for peptide drugs. Pharm. Res. 1994, 11, 1186-1189. [CrossRef]

253. William, H.; Frey, I. Intranasal delivery: Bypassing the blood-brain barrier to deliver therapeutic agents to the brain and spinal cord. Drug Deliv. Technol. 2002, 2, 46-49.

254. Ross, T.; Martinez, P.; Renner, J.; Thorne, R.; Hanson, L.; Frey, W., II. Intranasal administration of interferon beta bypasses the blood-brain barrier to target the central nervous system and cervical lymph nodes: A non-invasive treatment strategy for multiple sclerosis. J. Neuroimmunol. 2004, 151, 66-77. [CrossRef] [PubMed]

255. Thorne, R.; Hanson, L.; Ross, T.; Tung, D.; Frey, W., II. Delivery of interferon- $\beta$ to the monkey nervous system following intranasal administration. Neuroscience 2008, 152, 785-797. [CrossRef] [PubMed]

256. Ilium, L. Chitosan and its use as a pharmaceutical excipient. Pharm. Res. 1998, 15, 1326-1331. [CrossRef]

(C) 2020 by the authors. Licensee MDPI, Basel, Switzerland. This article is an open access article distributed under the terms and conditions of the Creative Commons Attribution (CC BY) license (http://creativecommons.org/licenses/by/4.0/). 